\title{
ArcheoSciences
}

Revue d'archéométrie

39 | 2015

Varia

\section{Agrarian legacies and innovations in the Nabataean territory}

Héritages et innovations agricoles en territoire nabatéen

\section{Charlène Bouchaud}

\section{(2) OpenEdition \\ 12 Journals}

\section{Electronic version}

URL: https://journals.openedition.org/archeosciences/4421

DOI: 10.4000/archeosciences.4421

ISBN: 978-2-7535-4778-0

ISSN: 2104-3728

Publisher

Presses universitaires de Rennes

\section{Printed version}

Date of publication: 31 December 2015

Number of pages: $103-124$

ISBN: 978-2-7535-4776-6

ISSN: $1960-1360$

\section{Electronic reference}

Charlène Bouchaud, "Agrarian legacies and innovations in the Nabataean territory", ArcheoSciences

[Online], 39 | 2015, Online since 31 December 2017, connection on 28 January 2022. URL: http:// journals.openedition.org/archeosciences/4421; DOI: https://doi.org/10.4000/archeosciences.4421

Article L.111-1 du Code de la propriété intellectuelle. 


\title{
Agrarian Legacies and Innovations in the Nabataean Territory
}

\author{
Héritages et innovations agricoles en territoire nabatéen
}

\author{
Charlène Bouchaud ${ }^{a}$
}

\begin{abstract}
The Nabataeans, a nomadic people inhabiting the southern Near East from the end of the $4^{\text {th }}$ century BC, are mainly known for their trade activities along the Incense Road. Recent scientific advances have shown the importance of agro-pastoral activities within the Nabataean kingdom. However, few studies have addressed the identification of the existing agrosystems and the kinds of associated plant production. This paper focuses on agrarian plant resources exploited in the Nabataean territory by analysing the carpological and anthracological data from four sites (Bosra, Dharih, Petra, Hegra) presented Nabataean and Roman layers dated between the $2^{\text {nd }}$ century BC and the end of the $3^{\text {rd }}$ century AD. The results obtained show the existence of farming systems combining annual and perennial crops, responding efficiently to different economic needs (including food, technical raw materials and fuel). Fruit trees were important and their distribution mainly correlated with climate and topographic constraints. Semi-arid sites developed Mediterranean agroforestry systems while the only arid area site developed an oasis agrosystem. Crop production was directly inherited from preceding periods while the presence of cotton in the Hegra oasis reflects innovative agricultural and technical processes probably related to Nabataean trade activities.
\end{abstract}

Résumé : Les Nabatéens, peuple nomade à l'origine, sinstallant dans le sud du Proche-Orient à partir de la fin du IV siècle av. J.-C., sont surtout connus pour leurs activités marchandes le long de la route de l'encens. Les avancées scientifiques récentes montrent l'importance des activités agro-pastorales à l'époque nabatéenne, mais peu d'études s'intéressent à la définition des agrosystèmes existants et aux types de productions végétales associées. Cet article propose donc de faire le point sur ce que nous savons des ressources végétales agricoles exploitées sur le territoire nabatéen par l'analyse des données carpologiques et anthracologiques de quatre sites (Bosra, Dharih, Pétra, Hégra) présentant des niveaux nabatéens et romains datés entre le II siècle av. J.-C. et la fin du III siècle apr. J.-C. Les résultats soulignent l'existence de systèmes agricoles mixtes associant cultures annuelles et pérennes, répondant efficacement aux différents besoins économiques (notamment alimentaires, techniques et combustibles). Les fruitiers y tiennent une place importante, et leur distribution est étroitement corrélée aux contraintes climatiques et topographiques. Les sites soumis à un climat semi-aride développent des systèmes agroforestiers méditerranéens tandis que le seul site soumis à un climat aride présente un agrosystème oasien. Les productions végétales sont directement héritées des périodes précédentes tandis que la présence de coton dans l'oasis de Hégra souligne une forme d'innovation agricole et technique probablement en lien avec l'activité commerciale nabatéenne.

Keywords: agriculture, archaeobotany, irrigation, Nabataean kingdom, trade.

Mots clés: agriculture, archéobotanique, irrigation, Nabatéens, commerce.

\section{INTRODUCTION}

The Nabataeans are originally nomadic and tribal Arab group gradually inhabited the southern part of the Near East in the $4^{\text {th }}$ century $\mathrm{BC}$, occupying already established cities and villages or building new settlements. The Nabataea as an independent kingdom persisted until AD 106 when it was annexed by the Roman emperor Trajan. Petra, its capital, was located at the crossroads of several large caravan routes coming from the southern Arabian Peninsula (Arabia Felix

a Archéozoologie, archéobotanique : Sociétés, pratiques et environnements (UMR 7209), Sorbonne Universités, Muséum, CNRS - CP56 55 rue Buffon, 75005 PARIS, France. (charlene.bouchaud@gmail.com) 
in Latin, today Yemen), the Persian Gulf in the east, Egypt and Mediterranean ports in the west and Syria in the north. During its greatest expansion between the $1^{\text {st }}$ century $\mathrm{BC}$ and the mid- $1^{\text {st }}$ century $A D$, the kingdom extended along three routes that crossed at Petra. The first went north to Bosra, the second to the west to Gaza and onwards to the Mediterranean ports north of the Sinai and the third to the south to Hedjaz and the site of Madâin Sâlih (ancient Hegra, Saudi Arabia). The eastern route remains difficult to perceive (Figure 1). The Nabataean civilization manifested in different forms that are materialized in particular by the existence of writing, clearly identified ceramic production and monetary systems and new architectural developments, especially funerary, ensuring the modern worldwide reputation of Petra (Bowersock, 1983; Nehmé \& Villeneuve, 1999; Wenning, 2007). Nabataean economy was long considered as relying principally on its commercial dimension, especially those discussed in Greek and Latin texts and more particularly those written by Diodorus of Sicily in the $1^{\text {st }}$ century BC (Library of History XIX.94.5). These described the Nabataeans as a nomadic people obtaining its wealth through long-distance trade in spices, incense and other exotic products between Arabia Felix and the Mediterranean world. Recent archaeological discoveries and analyses have largely qualified this view by pointing out on one hand the complex, mixed and permeable nature of nomadic and sedentary modes of occupation developing in the Nabataean kingdom (Tholbecq, 2013: 3-4) since the very start of occupation (Graf, 2013; Renel \& Mouton, 2013) and on the other the difficulty in demonstrating material evidence of such commerce (Durand, 2008; Durand \& Gerber, 2014). After the annexation of the Nabataean kingdom under Trajan, the territory of the new Roman province embraces the limits of the former Nabataean kingdom with Bosra as its new capital (Bowersock, 1983; Graf, 2007). This political event was not reflected in a halt in Nabataean activities and production, which remained visible for more than a century and a half, indicating the existence of a still prosperous economy (Fiema, 2003: 49-50). Annexation was accompanied, however, by significant architectural renovations, like those at the sites of Dharih (Villeneuve \& Al-Muheisen, 1994, 2008) and Hegra (Al-Talhi \& Al-Daire, 2005; Villeneuve, 2014: 28), and new construction in large urban centers, such as Petra (Bedal et al., 2013; Fiema, 2003) and Bosra (Sartre, 2007).

While dynamic scientific research in the region regularly uncovers major aspects of Nabataean civilization, understanding of the role of agrarian economy in its development and our knowledge of established agrarian systems and associated production remain limited. This article thus focuses on agricultural plant resources based on archaeobotanical data collected at Nabataean sites, attempting to identify patterns of inheritance and innovation over time. Rather than claim to be a study of "Nabataean agriculture", which would imply giving an ethnic meaning to data silent on the subject, the objective of the present contribution is to report on the spatial and temporal dynamics of agrarian system in the Nabataean territory during Nabataean and Roman periods - between the $2^{\text {nd }}$ century $\mathrm{BC}$ and the $3^{\text {rd }}$ century $\mathrm{AD}^{2}$ - in light of carpological and anthracological data from Bosra (southern Syria), Dharih (Jordan), Ez Zantur (Petra, Jordan) and Hegra (Saudi Arabia).

\section{THE REGION AND STUDY SITES}

\section{Topography and vegetation of the southern Near East}

The southern part of the Near East is organized in parallel bands marked by the rift depression that crosses the region from the Red Sea, rises toward the Dead Sea and is followed by the Jordan Valley and the Beqaa valley. Mountainous, semi-mountainous and plateau zones located east of this fault gradually descend eastward towards steppe and desert zones (Sanlaville, 2000: 11-22). The modern climate is Mediterranean, marked by minor and irregular winter precipitation decreasing in intensity on west-east and northsouth gradients and superimposed by local effects linked to topography (Sanlaville, 2000: 48-54). Modern wild vegetation, although very limited, also expresses strong dynamics (Zohary, 1973). Mediterranean flora is dominant to the west and north, represented among others by tree formations with Palestine oak (Quercus calliprinos) and Aleppo pine (Pinus halepensis). Steppe flora, such as the wild pistachio tree (Pistacia atlantica) and shrub cover, is more important in the east and desert vegetation dominates in the southern zones with open formations with umbrella thorn (Acacia tortilis subsp. tortilis and subsp. raddiana). Access to water is crucial, with significant implications for the economy, occupation strategies and agricultural techniques in Near Eastern societies. In most of the northern territories of the Nabataea,

1. Note that the treatise on Nabataean agriculture, Kitab al-falaha alnabatiya, written in Syriac by Qûtâma in the $3^{\text {rd }}-4^{\text {th }}$ c. AD but known only by the ca. $904 \mathrm{AD}$ Arabic translation by Ibn Wahshîyya, actually refers to a Mesopotamian agronomic tradition entirely unrelated to the Nabataean kingdom (El Faïz, 1995; Hämeen-Anttila, 2006).

2. Although the $3^{\text {rd }}$ century AD is the chronological limit for this study, the end of the Roman period in the region is generally put during the second half of the $4^{\text {th }}$ century $\mathrm{AD}$, when most of the sites mark a decline or a stop of their occupation, as in Petra (Fiema, 2003). 


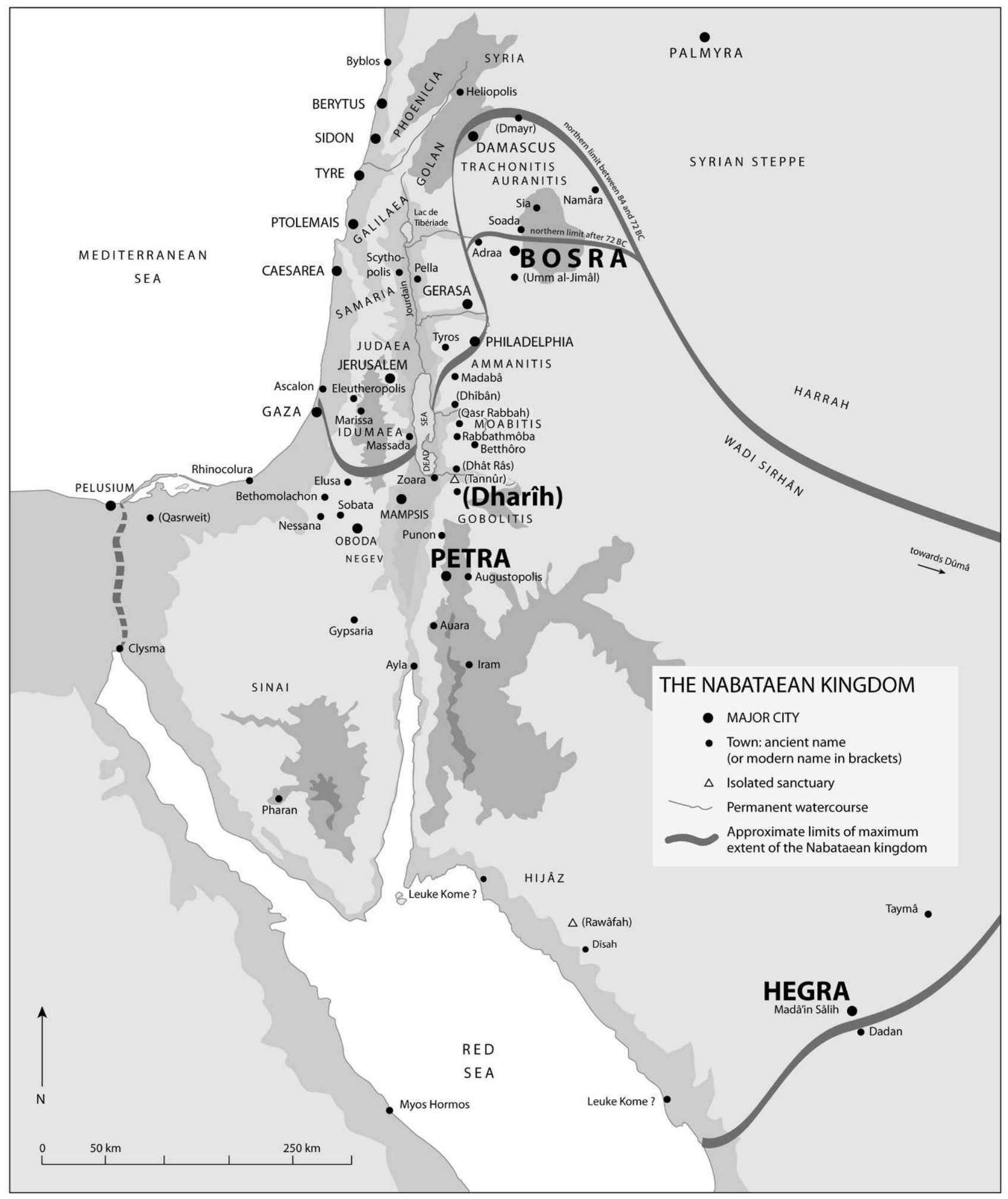

Figure 1: Map of the Nabataean kingdom (after Nehmé \& Villeneuve 1999, p. 164).

Figure 1: Carte du royaume nabatéen (d'après Nehmé et Villeneuve 1999, p. 164). 
and in the highest altitude zones (e.g., around Wadi Musa in the Petra region or modern Amman), annual precipitation today oscillating between 250 and 300-400 mm per year and perhaps slightly higher during Antiquity (Rambeau, 2010: 5229), is just sufficient for productive dry agriculture. But elsewhere, in the plains and plateau around Petra, the Dead Sea and the southern regions, direct irrigation systems or recuperation of rainwater are sometimes essential for crop maintenance (Oleson, 2001).

\section{Presentation of sites (Table 1)}

Bosra is a major city founded at least during the $2^{\text {nd }}$ mill. BC (Braemer, 2002) and occupied during Antiquity, marking the northern limit of the Nabataean kingdom from the end of the $1^{\text {st }}$ century BC (Dentzer et al., 2001: 466). It became the capital of the Roman province of Arabia in the $2^{\text {nd }}$ century AD (Sartre, 2007). The city is located on a basalt plateau poor in natural plant resources but for which the flat topography and fertile soils were as yet largely unexploited for cereal crops (Leblanc, 2007). Dharih is a small rural village where a shrine developed during the $1^{\text {st }}$ century $\mathrm{AD}$ and especially after Roman annexation (Villeneuve \& Al-Muheisen, 2008). The site is located on the slope of a steep-walled valley (Bossut, 2010: 116-117). Today, conditions less humid than at Bosra nonetheless allow dry farming of hulled barley (Hordeum vulgare subsp. distichon) and irrigated farming of olive (Olea europaea) and pomegranate trees (Punica granatum). Ez Zantur is a group of houses in the lower town of Petra that developed between the $2^{\text {nd }}$ century $\mathrm{BC}$ and the second half of the $4^{\text {th }}$ century AD (Bignasca et al., 1996; Grawehr, 2010; Keller \& Grawehr, 2006; Kolb, 2003). The sandstone massif on which the ancient city of Petra was built has an extremely rugged relief marginal for agricultural activities. Today these mainly take place outside the rock enclosure in the better-watered heights of the region (Besançon, 2010). The city of Madầ in Sâlih, or ancient Hegra, is located on a vast desert plain surrounded by mountain massifs (Courbon, 2008: 49-54; Nehmé et al., 2006: 54-58). Occupied since the $4^{\text {th }}-3^{\text {rd }}$ centuries BC (Charloux, 2011: 31; Durand \& Gerber, 2014), it was densely inhabited from the $2^{\text {nd }}-1^{\text {st }}$ centuries $B C$ to the $4^{\text {th }}$ century AD at least (Nehmé et al., 2006: 51). Low precipitation in the region, ranging between 50 and $100 \mathrm{~mm}$ per year, is compensated by the presence of groundwater largely exploited today to irrigate the imposing palm groves grown in the oasis located to the north of the ancient city (Nehmé et al., 2006: 59).

\section{Agriculture in the Nabataean kingdom: Texts and archaeology}

Our perception of agriculture in the Nabataean kingdom still depends mainly on the interpretation of the Greek and Latin texts of Diodorus of Sicily (Library of History II.48.1, XIX.94.2) and Strabo (Geographica XVI.4.21/26). Without

\begin{tabular}{|l|c|c|c|c|c|c|}
\hline Site & $\begin{array}{c}\text { Altitude } \\
(\mathrm{m})\end{array}$ & $\begin{array}{c}\text { Topographic } \\
\text { situation }\end{array}$ & Soil type & $\begin{array}{c}\text { Annual precipita- } \\
\text { tion (mm) }\end{array}$ & Dominant vegetation & Main water resource \\
\hline Bosra & 850 & Plateau & Clayey on basalt & $250-300$ & $\begin{array}{c}\text { Irano-Touranian with Mediter- } \\
\text { ranean influence: relict forest- } \\
\text { steppe (pistachio) }\end{array}$ & $\begin{array}{c}\text { Nearby perennial spring, } \\
\text { plateau wadis, Djebel } \\
\text { Hauran springs }\end{array}$ \\
\hline Dharih & $\begin{array}{c}700 \text { to } \\
750\end{array}$ & $\begin{array}{c}\text { Valley base and } \\
\text { slopes }\end{array}$ & $\begin{array}{c}\text { Limestone and } \\
\text { fersiallitic clay }\end{array}$ & 200 & $\begin{array}{c}\text { Mediterranean influence in } \\
\text { the heights (juniper), Irano- } \\
\text { Touranian and Saharo-Arabian } \\
\text { vegetation concentrated on the } \\
\text { plain (broom, tamarisk) }\end{array}$ & $\begin{array}{c}\text { Perennial springs and } \\
\text { wadis }\end{array}$ \\
\hline Petra & $\begin{array}{c}860 \text { to } \\
1000\end{array}$ & $\begin{array}{c}\text { Steep valley } \\
\text { slopes, plateau, } \\
\text { hills, semi- } \\
\text { mountainous }\end{array}$ & $\begin{array}{c}\text { Sandstone and } \\
\text { limestone }\end{array}$ & $\begin{array}{c}\text { Mediterranean influence in the } \\
\text { heights (oak, hawthorn, juniper); } \\
\text { Irano-Touranian and Saharo- } \\
\text { Arabian vegetation concentrated } \\
\text { around water sources (broom, } \\
\text { tamarisk) }\end{array}$ & Perennial springs and \\
wadis
\end{tabular}

Table 1: Summary of the principal biotic and abiotic characteristics of the sites studied.

Tableau 1 : Résumé des principales caractéristiques biotiques et abiotiques des sites étudiés. 
denying the importance of information that such sources can contribute, these texts suggest a fragmentary vision limited to the Petra region of the population of nomadic pastoralists and merchants (Diodorus of Sicily) gradually adopting a more sedentary way of life based on agriculture (Strabo) (Kouki, 2009: 44-45). Agriculture during the Nabataean period has been the subject of several recent archaeological projects focusing primarily on irrigation systems in the Negev (Erickson-Gini, 2012), the Hegra region (Courbon, 2008) and Petra (Al-Muheisen, 2009; Gentelle, 2009) and its neighboring region (Oleson, 2007, 2010). Overall information on the initial period of Nabataean occupation, between the $4^{\text {th }}$ and $2^{\text {nd }}$ centuries $\mathrm{BC}$, is still quite limited (Mouton \& Schmid, 2013) and even less so for agricultural economy (Kouki, 2009, 2013: 324; Tholbecq, 2013: 5). Recent archaeological research shows that the development of agrarian activity at Nabataean sites, particularly at Petra, can be observed in the archaeological record in the $1^{\text {st }}$ century AD (Kouki, 2009; Tholbecq, 2013). This phenomenon is accompanied by the maintenance of long-distance trade contacts (Fiema, 2003: 43; Kouki, 2013: 323; Wenning, 2007: 40).

\section{Material AND METhods}

The present study is based on the recovery of cultivated, or potentially cultivated, charred plant remains at the four study sites. Wild plants are not included in the discussion in this article ${ }^{3}$. The dataset includes the common broad food and/or technical categories (cereals, pulses, fruits, oil/textile and condiments).

\section{Chronology and samples}

Each site has occupation levels covering at least part of the three chronological divisions selected for the analysis: the Early Nabataean (early $2^{\text {nd }}$ century - mid- $1^{\text {st }}$ century BC), the Classical Nabataean (mid- $1^{\text {st }}$ century $\mathrm{BC}$ - early $2^{\text {nd }}$ century AD) and the Nabataeo-Roman (early $2^{\text {nd }}$ century $\mathrm{AD}$ - end $3^{\text {rd }}$ century $\left.\mathrm{AD}\right)^{4}$. Radiocarbon dates on seeds or leaves confirm the chronology of some occupations established by relative dating at Bosra and Hegra (Table 2). Samples from the early periods at Hegra (Early and Classical Nabataean) provide absolute dates slightly different from proposed relative dates and encourage us to consider with caution the chronological limits that have been set.

The archaeological contexts studied are all open domestic or craft-related assemblages (dumps and waste zones, occupation level, kiln, hearths and hearth waste) where the presence of plant remains is in majority due to a mixture of waste and combustible elements. These come from sector BAT at Bosra (Bouchaud, 2012), sectors V1, V2, V10, S2, S3, B3 at Dharih, residential terraces Ez Zantur I, II, III and IV at Petra and the residential sector (Areas 1, 20, 21, 22, 25, 31, 8) at Hegra (Bouchaud, 2013).

\begin{tabular}{|c|c|c|c|c|c|c|c|c|c|}
\hline \multirow{2}{*}{ Site } & \multirow{2}{*}{$\mathrm{Lab}^{\circ}$} & \multirow{2}{*}{$\mathrm{US} \mathrm{n}^{\circ}$} & \multirow{2}{*}{ Material } & \multirow{2}{*}{ Periods } & \multirow{2}{*}{$14 \mathrm{C}$} & \multirow{2}{*}{$\delta 13 \mathrm{C}$} & \multicolumn{3}{|c|}{$95.4 \% *$} \\
\hline & & & & & & & From & To & $\mathrm{p}$ \\
\hline \multirow{3}{*}{ BOSRA ** } & UBA-20564 & BAT 2205 & Cereal grain & Nabataeo-Roman & $1787 \pm 30 \mathrm{BP}$ & -20.4 & 209 & 348 & 0.923 \\
\hline & UBA-20563 & BAT 2272 & Cereal grain & Nabataeo-Roman & $1781 \pm 47 \mathrm{BP}$ & -26.4 & 129 & 359 & 0.971 \\
\hline & UBA-20562 & BAT 2245 & Cereal grain & Nabataeo-Roman & $1767 \pm 28 \mathrm{BP}$ & -21.8 & 133 & 264 & 0.732 \\
\hline \multirow{4}{*}{ HEGRA *** } & Lyon-9763 & 25084 & Date seed & "Early Nabataean" **** & $2080 \pm 30 \mathrm{BP}$ & & -191 & -38 & 0.989 \\
\hline & Lyon-6671 & 20026 & Date palm leaf & Nabataeo-Roman & $1850 \pm 30 \mathrm{BP}$ & & 85 & 235 & 1 \\
\hline & Lyon-9754 & 80124 & Cotton seed & Nabataeo-Roman & $1815 \pm 30 \mathrm{BP}$ & & 126 & 257 & 0.939 \\
\hline & Lyon-9755 & 80106 & Cotton seed & Nabataeo-Roman & $1850 \pm 30 \mathrm{BP}$ & & 85 & 235 & 1 \\
\hline
\end{tabular}

* Calibration IntCal.09.14c (Reimer et al., 2009).

** Dates obtained from the 14Chrono Laboratory of Queens University (Belfast, Ireland).

*** Dates obtained from the Carbon Dating Centre (Lyon, France).

**** The so-called "Early Nabataean" period corresponds to real old Nabataean occupation in Petra but not in Hegra, where Nabataean population probably came at the end of the 1st century BC. For this site, the term "Early Nabataean" is indicated with brackets and only used as chronological marker without cultural reference.

Table 2: Radiocarbon dates obtained at Bosra and Hegra. Tableau 2 : Datations radiocarbones réalisées à Bosra et Hégra.
3. Some of the results on which this study is based have already been published, in particular the data from Bosra (Bouchaud, 2012) and Hegra (Bouchaud, 2013; Bouchaud et al. 2012).

4. For ease of reading, these periods are represented in numbers rounded to the nearest century in diagrams and tables. 


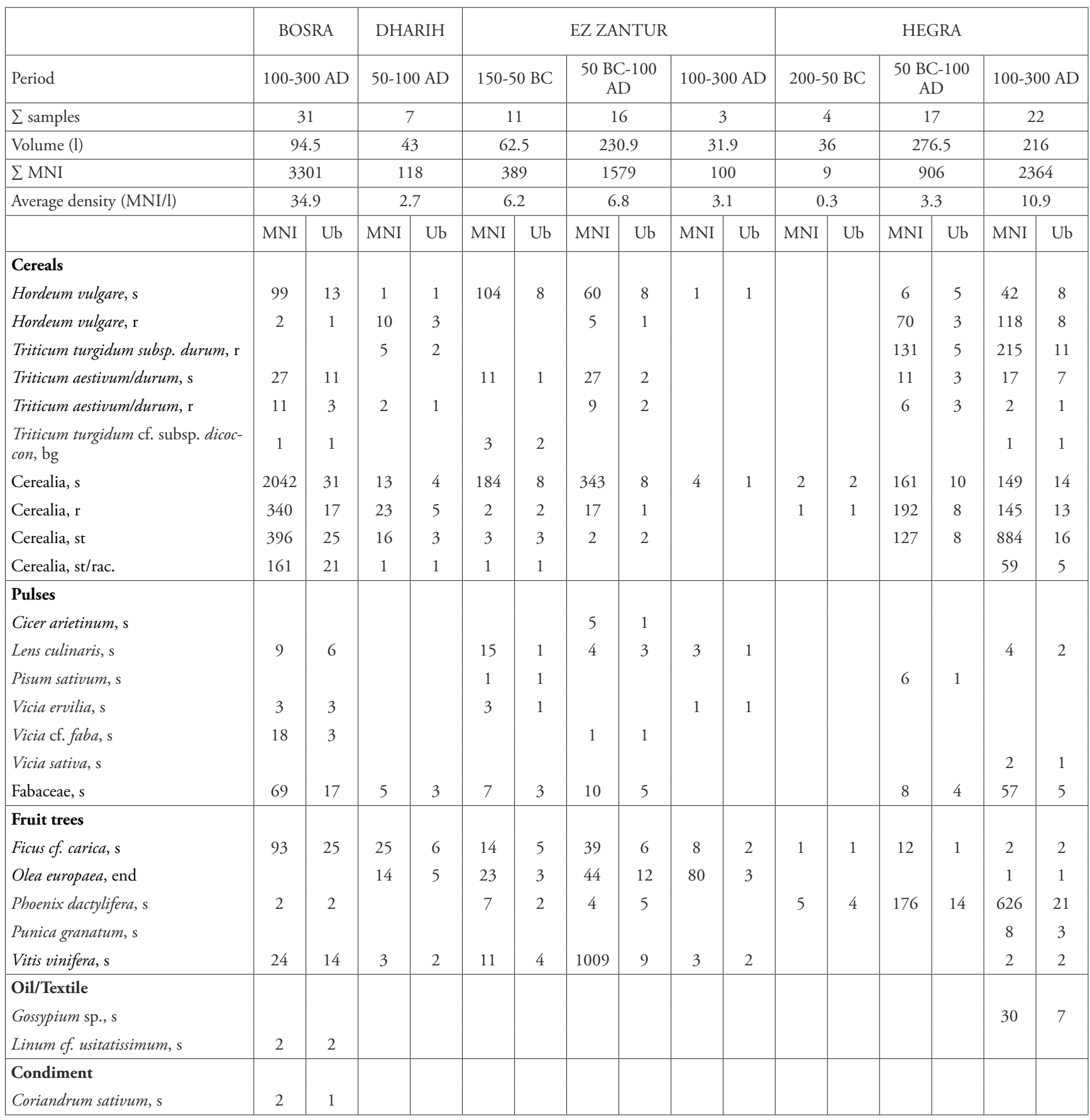

Table 3: Carpological results - Minimum Number of Individuals (MNI) and ubiquity (Ub) of cultivated plants at Bosra, Dharih, Ez Zantur (Petra) and Hegra. $s=$ seed, $r=$ rachis, bg = glume base, $s t=s t e m, ~ s t / r a c=s t e m /$ root base, end = endocarp Tableau 3 : Résultats carpologiques - Nombre minimum d'individu (NMI) et occurrence des plantes cultivées à Bosra, Dharih, Ez Zantur (Petra) et Hégra. $s=$ graine, $r=$ rachis, $b g=$ base de glume, st = tige, st/rac = base de tige/racine, end $=$ endocarpe 


\section{Selection and quantification of carpological samples}

Carpological samples selected all come from sediment samples (from 0.5 to 115 liters) from the different occupation levels. These were sieved or floated using $0,5 \mathrm{~mm}$ sieves. Hand-picked remains collected during excavation were excluded from the selection process.

The carpological analysis (Table 3) is based on the number of seeds or other plant parts identified in the samples as cultivated plants. These numbers represent the minimum number of individuals present and not the number of fragments. The remains of bracts of cereals (glumes, lemma and palea), olive seeds, grape pedicels, date perianths were excluded from the study since these elements would provide redundant quantitative information with respect to other kinds of remains already represented for the same species (rachis segment, olive endocarps, grape seeds, date seeds).

The number of samples studied differs by site due to the combined effect of archaeobotanical investment at each of the sites and the archaeological representativeness for each period. The Early Nabataean (early $2^{\text {nd }}$ century - mid- $1^{\text {st }}$ century BC) is the least represented and is visible only at Ez Zantur (number of samples, $n=11)$ and $\operatorname{Hegra}^{5}(n=4)$. The Classical Nabataean (mid- $1^{\text {st }}$ century BC - early $2^{\text {nd }}$ century $A D)$ is present at Dharih $(n=7)$, Ez Zantur $(n=17)$ and Hegra $(n=17)$. The Nabataeo-Roman period (early $2^{\text {nd }}$ century AD - end $3^{\text {rd }}$ century $\mathrm{AD}$ ) is represented at Bosra (n $=31)$, Ez Zantur $(n=4)$ and Hegra $(n=22)^{6}$. The low number of samples $(\mathrm{n}=15)$ and remains $(\mathrm{MNI}=398)$ observed for the Early Nabataean and more generally for the site of Dharih ${ }^{7}$, as well as the disparity of the contexts and differential representativeness of the taxa at each site introduce considerable methodological biases necessarily affecting the quantitative analysis of the data (Figure 2) and their interpretation in cultural and chronological terms (Lee, 2012; Van der Veen \& Fieller, 1982). To reduce these disparities and to allow comparison between sites, the minimum number of remains are weighted by the sample volume collected (Figure 2). Moreover, we have opted for a semi-quantitative analysis of the results, based principally on the frequencies

5. See note 8 .

6. Samples from the Nabataean period at Bosra (Willcox, 2003) and the Roman period at Dharih (Bouchaud, 2011: 142-143) have been studied, but some problems of chronological limits and the small number of remains makes the data unusable.

7. Note that a large number of samples have been studied at this site, but these are from periods not included in the present study (Late Antiquity and the start of the Islamic period) (Bouchaud, 2011: 133-158, 2014: 601). of each taxon (Figure 3) ${ }^{8}$. Correspondence analysis (CA) results $^{9}$ (Figure 4) are based only on the periods at each site that are represented by minimum number of remains greater than 100 . Here, quantitative data are processed using an abundance scale (Bouby \& Marinval, 2004) with four classes (class 1: $\leq 2 \%$ [taxon representing less than $2 \%$ of the total number of cultivated plants], class $2: 2-15 \%$, class 3: $15-50 \%$, class $4:>50 \%$ ). In addition, the number of remains of rachis fragments has been converted into the equivalent number of caryopses (grains): a rachis segment of barley (Hordeum vulgare) able to bear one to three caryopses depending on sub-species (2-row, $H$. vulgare subsp. distichon or 6-row, $H$. vulgare subsp. vulgare), the number of remains is multiplied by two. A segment of free-threshing wheat rachis (bread wheat, Triticum aestivum subsp. aestivum or hard wheat, Triticum turgidum subsp. durum) having on average three caryopses, the number of segments was multiplied by three (Cappers \& Neef, 2012: 388). Unidentified cereal rachis fragments were arbitrarily multiplied by two. Cereal culm and root fragments were excluded.

\section{Selection and quantification of anthracological samples}

The anthracological samples selected include wood charcoal recovered from bulk sediment samples (from 0.5 to 90 l) collected from the different occupation layers at each site, sieved to $0,5 \mathrm{~mm}$. Most of the sediment samples are the same as for carpological study; others only contained wood charcoal residues. It was also decided to include the hand-picked fragments recovered during excavation (collected directly or after sieving at $5 \mathrm{~mm}$ ) of the sectors for which sediment samples had not been collected, e.g., at Dharih and Ez Zantur. The analysis is based on the total number of charcoal fragments studied. Cultivated, or potentially cultivated, plants were individually separated and the other taxa, corresponding to other vegetation types, were grouped. Unidentified and unidentifiable fragments were excluded (Table 4).

The number of charcoal samples studied varies greatly from one site to another due to the same biases affecting the carpological analysis (investment and representativeness). The consequences are comparable: the "Early Nabataean" is represented at Ez Zantur (number of samples, $\mathrm{n}=10$, number of fragments, $\mathrm{N}=43)$ and Hegra $(\mathrm{n}=4, \mathrm{~N}=449)$; the Classic Nabataean is present at Dharih $(\mathrm{n}=7, \mathrm{~N}=297)$, Ez Zantur $(\mathrm{n}=11, \mathrm{~N}=147)$ and Hegra $(\mathrm{n}=12, \mathrm{~N}=883)$.

8. Proportion of the number of samples where a taxon is present relative to the total number of samples studied by site and by period.

9. MS Excel macro CAPCA Version 2.2 (Torsten Madsen (C2012). 


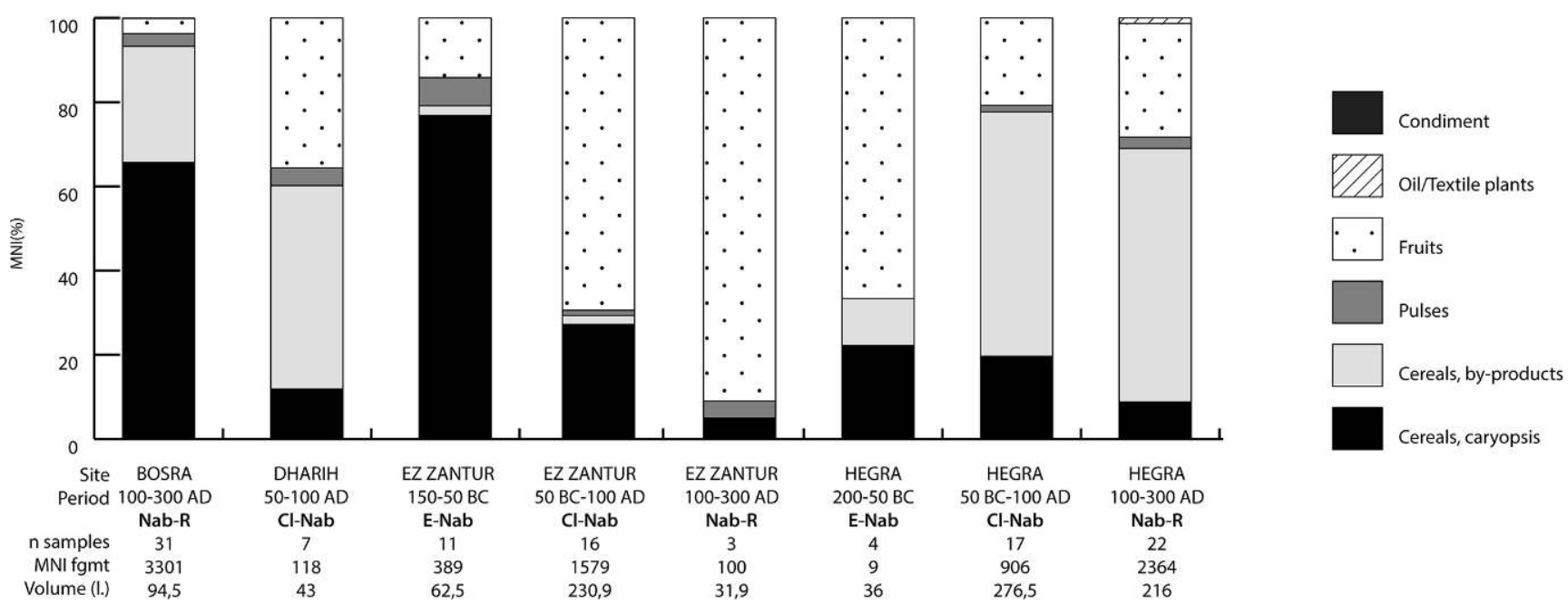

Figure 2: Proportion of plant groups represented by site and period calculated from carpological remains (minimum number of individuals [MNI]).

E-Nab = Early Nabataean; Cl-Nab = Classical Nabataean; Nab-R = Nabataeo-Roman

Figure 2 : Proportion des catégories végétales représentées par site et période calculée à partir des restes carpologiques (nombre minimum d'individus NMI)

E-Nab = Nabatéen ancien; $C l-N a b=$ Nabatéen classique; $N a b-R=$ Nabatéo-romain

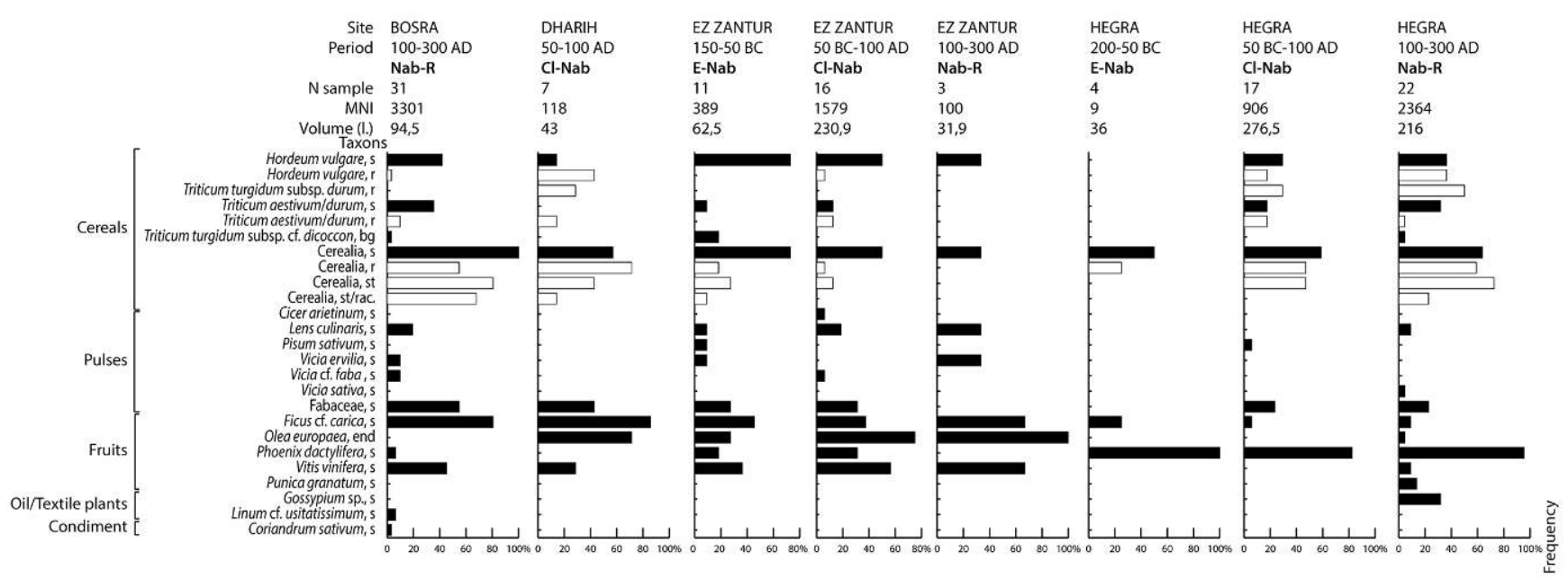

Figure 3: Frequency of carpological taxa by site and period. The cereal by-products are represented with white bars.

E-Nab = Early Nabataean; Cl-Nab = Classical Nabataean; Nab-R = Nabataeo-Roman

Figure 3 : Fréquence d'attestation des taxons carpologiques par site et par période. Les sous-produits céréaliers sont représentés par des barres blanches.

E-Nab = Nabatéen ancien; $C l-N a b=$ Nabatéen classique; $N a b-R=$ Nabatéo-romain 


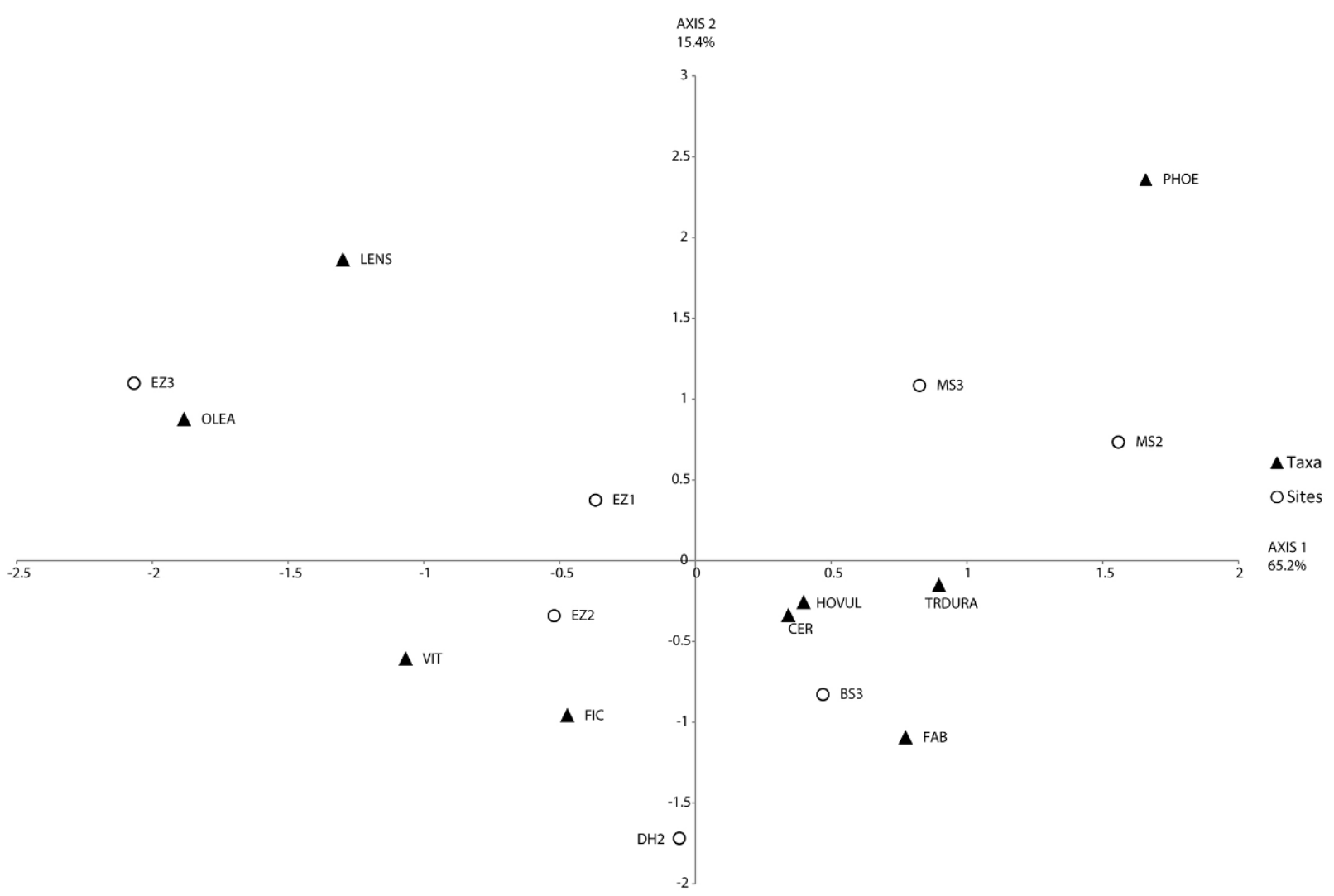

Figure 4: Correspondence analysis (CA) for sites (objects) and carpological remains (variables). BS = Bosra, DH2 = Dharih, Classical Nabataean period, DH3 = Dharih, Nabataeo-Roman period, EZ1 = Ez Zantur, Early Nabataean period, EZ2 = Ez Zantur, Classical Nabataean period, EZ3 = Ez Zantur, Nabataeo-Roman period, MS1 = Hegra, Early Nabataean period, MS2 = Ez Zantur, Classical Nabataean period, MS3 = Ez Zantur, Nabataeo-Roman period. HOVUL = Hordeum vulgare, TRDURA = Triticum turgidum subsp. durum + T.aestivum/durum, CER = Indeterminate Cerealia, FAB = Indeterminate Fabaceae, LENS = Lens culinaris, FIC = Ficus $\mathrm{cf}$. carica, OLEA = Olea europaea, $\mathrm{PHOE}=$ Phoenix dactylifera, VIT = Vitis vinifera

Figure 4: Analyse factorielle des correspondances des sites (objets) et des restes carpologiques (variables). BS = Bosra, DH2 = Dharih, époque nabatéenne classique, $D H 3=$ Dharih, époque nabatéo-romaine, $E Z 1=E z Z a n t u r$, époque nabatéenne ancienne, EZ2 = Ez Zantur, époque nabatéenne classique, EZ3 = Ez Zantur, époque nabatéo-romaine, $M S 1=$ Hégra, époque nabatéenne ancienne, MS2 = Ez Zantur, époque nabatéenne classique, $M S 3=E z$ Zantur, époque nabatéo-romaine. HOVUL = Hordeum vulgare, TRDURA = Triticum turgidum subsp. durum $+\mathrm{T}$. aestivum/durum, CER $=$ Cerealia indéterminées, FAB $=$ Fabaceae indéterminées, LENS $=$ Lens culinaris, FIC $=$ Ficus cf. carica, $O L E A=$ Olea europaea, $P H O E=$ Phoenix dactylifera, $V I T=$ Vitis vinifera

The Nabataeo-Roman period is the best represented in total number of samples and fragments, present at Bosra $(\mathrm{n}=18, \mathrm{~N}=241)$, Dharih $(\mathrm{n}=21, \mathrm{~N}=822)$ and Hegra ( $\mathrm{n}$ $=18, \mathrm{~N}=2541$ ). The charcoal study does not include the Nabataeo-Roman period at Ez Zantur. However, the study provides information about this period at Dharih, which is not covered by the carpological study. Anthracological data are analyzed by percentage of the number of remains and by frequency for each period and at each site (Figure 5).

\section{RESULTS}

\section{Cereals}

Cereals are a key group at all four sites, representing more than half of the cultivated remains identified by the carpological study, apart from Hegra during the "Early Nabataean" and Ez Zantur during the Classic Nabataean and NabateaoRoman periods (Figure 2). All elements of the ear have been found (Table 3): caryopses, rachis segments, stem and root fragments ${ }^{10}$. Many of these remains are poorly preserved and

10. Cereal husks are excluded from the analysis and thus not represented in Table 3. 


\begin{tabular}{|c|c|c|c|c|c|c|c|c|c|c|c|c|c|c|c|c|}
\hline & \multirow{2}{*}{\multicolumn{2}{|c|}{$\begin{array}{c}\text { BOSRA } \\
100-300 \mathrm{AD}\end{array}$}} & \multicolumn{4}{|c|}{ DHARIH } & \multicolumn{4}{|c|}{ EZ ZANTUR } & \multicolumn{6}{|c|}{ HEGRA } \\
\hline Period & & & \multicolumn{2}{|c|}{ 50-100 AD } & \multicolumn{2}{|c|}{$100-300 \mathrm{AD}$} & \multicolumn{2}{|c|}{$150-50 \mathrm{BC}$} & \multicolumn{2}{|c|}{$\begin{array}{c}50 \mathrm{BC}-100 \\
\mathrm{AD}\end{array}$} & \multicolumn{2}{|c|}{$200-50 \mathrm{BC}$} & \multicolumn{2}{|c|}{$\begin{array}{c}50 \mathrm{BC}-100 \\
\mathrm{AD}\end{array}$} & \multicolumn{2}{|c|}{$100-300 \mathrm{AD}$} \\
\hline$\sum$ samples & \multicolumn{2}{|c|}{18} & \multicolumn{2}{|c|}{7} & \multicolumn{2}{|c|}{21} & \multicolumn{2}{|c|}{10} & \multicolumn{2}{|c|}{11} & \multicolumn{2}{|c|}{4} & \multicolumn{2}{|c|}{12} & \multicolumn{2}{|c|}{18} \\
\hline Volume (1.) & \multicolumn{2}{|c|}{75} & \multicolumn{2}{|c|}{43} & \multicolumn{2}{|c|}{125} & \multicolumn{2}{|c|}{43.6} & \multicolumn{2}{|c|}{24.9} & \multicolumn{2}{|c|}{36} & \multicolumn{2}{|c|}{122} & \multicolumn{2}{|c|}{211.5} \\
\hline$\sum$ hand-picked samples & & & & & \multicolumn{2}{|c|}{15} & \multicolumn{2}{|c|}{4} & & & & & & & & \\
\hline & NR & $\mathrm{Ub}$ & NR & $\mathrm{Ub}$ & NR & Ut & NR & $\mathrm{Ub}$ & $\mathrm{NP}$ & 0 & NR & $\mathrm{Ub}$ & $\mathrm{N}$ & $\mathrm{U}$ & NR & $\mathrm{Ub}$ \\
\hline Olea europaea & 145 & 13 & 161 & 7 & 452 & 16 & 2 & 1 & 3 & 3 & 0 & 0 & 10 & 1 & 2 & 2 \\
\hline Vitis vinifera & 43 & 6 & 0 & 0 & 3 & 1 & & & & & & & & & & \\
\hline Phoenix dactylifera & 0 & & 2 & 2 & 0 & 0 & & & & & 80 & 4 & 30 & 1 & 1308 & 18 \\
\hline Ficus cf. carica & 0 & & 13 & 3 & 0 & 0 & & & 10 & 1 & & & & & & \\
\hline Punica granatum & 0 & & 0 & 0 & 1 & 1 & & & & & 7 & 1 & 5 & 1 & 1 & 1 \\
\hline Other plant formations & 53 & 13 & 121 & 7 & 366 & 14 & 41 & 10 & 13 & 1 & 362 & 4 & 56 & 1 & 1230 & 18 \\
\hline
\end{tabular}

Table 4: Anthracological results - Number of remains (NR) and ubiquity (Ub) of cultivated plants at Bosra, Dharih, Ez Zantur (Petra) and Hegra.

Tableau 4 : Résultats anthracologiques - Nombre de restes (NR) et occurrence des plantes cultivées à Bosra, Dharih, Ez Zantur et Hégra.

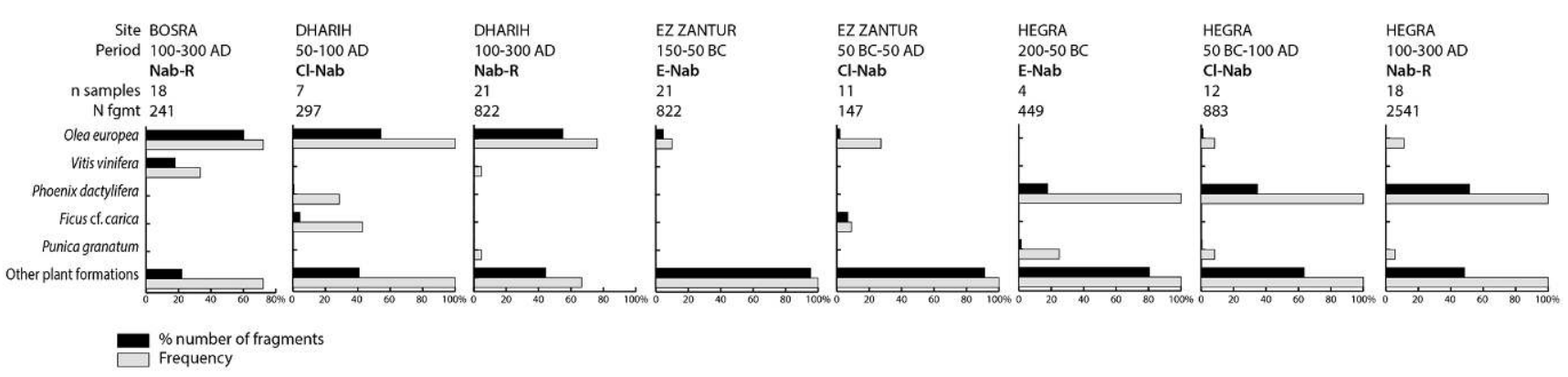

Figure 5: Proportions and frequencies of anthracological remains by site and period. E-Nab = Early Nabataean; Cl-Nab = Classical Nabataean; Nab-R = Nabataeo-Roman

Figure 5: Proportions et fréquences d'attestation des restes anthracologiques par site et par période. E-Nab = Nabatéen ancien; Cl-Nab = Nabatéen classique; $N a b-R=N a b a t e ́ o-r o m a i n ~$

others (such as stem and root elements) cannot be precisely identified. All of these elements together are thus determined only to family (Cerealia). Among the well-identified elements, three species groups can be recognized: hulled barley (Hordeum vulgare), free-threshing wheat (Triticum aestivum/durum) and emmer wheat (Triticum turgidum subsp. dicoccon). Rachis segments of well-preserved hulled barley at Dharih and Hegra show the presence of 2-row barley (H. vulgare subsp. distichon) and 6-row barley (H. vulgare subsp. vulgare) (Bouchaud 2013: 13). Caryopses of free-threshing wheat cannot be differentiated to the level of species and they have been grouped under the general term T. aestivum/durum. Some rachis fragments have clearly visible traits that allow identification as durum wheat (T. turgidum subsp. durum) at Dharih and Hegra. No cer- tain identification of T. aestivum subsp. aestivum has been made on the material studied for these periods. Barley is the most common cereal, present as caryopses and rachis segments at Bosra, Dharih and Ez Zantur while at Hegra, durum wheat is represented in equivalent proportions for the Classic Nabataean and slightly higher for the NabataeoRoman period. Emmer wheat is present only as rare glume bases found in the older layers at Ez Zantur, and in the Nabataeo-Roman layers at Bosra and Hegra. (Figure 3).

\section{Pulses}

Cultivated pulses are never more than $7 \%$ of the minimum number of carpological remains (Figure 2). Many are unidentifiable due to poor preservation. Six different 
species can, however, be recognized: chickpea (Cicer arietinum), lentil (Lens culinaris), pea (Pisum sativum), bitter vetch (Vicia ervilia), fava bean (Vicia cf. faba) and common vetch (Vicia sativa). Lentil is the most common pulse, present in all periods and five of the eight assemblages studied (Figure 3). It is best represented at Ez Zantur during the Classic Nabataean (present in 19\% of the samples) and the Nabataeo-Roman period (33\%). Bitter vetch is found at least in two sites (Bosra and Ez Zantur) while the other species are a minority. No pulses were found at Hegra during the Early Nabataean and only a few unidentifiable large pulses were found at Dharih.

\section{Fruit trees}

Fruit remains in the form of seeds and endocarps (stones) dominate the carpological assemblages at Hegra during the "Early Nabataean" and at Ez Zantur during the Classic Nabataean and Nabataeo-Roman periods. Elsewhere, or for other periods, they constitute between $14 \%$ and $30 \%$ of the assemblage and form at least $4 \%$ of the minimum number of items at Bosra (Figure 2). Five species are represented: fig (Ficus cf. carica), olive (Olea europaea), pomegranate (Punica granatum), date (Phoenix dactylifera) and grape (Vitis vinifera). Figs are present at all of the sites and during all occupation periods. Olive endocarps and grape seeds are particularly common at Dharih and Ez Zantur (Figure 3). For these latter sites, the frequency of these two species increases through time (from 36\% to $67 \%$ for grapes, and from $27 \%$ to $100 \%$ for olives). Both appear only during the Nabataeo-Roman period at Hegra while pomegranate is found only at this site. Date seeds are very common at Hegra, starting with the Early Nabataean. They are also present in the Early and Classic Nabataean layers at Ez Zantur and in small proportions (6\% of the samples) at Bosra during the Nabataeo-Roman period.

The anthracological analysis also shows the presence of wood charcoal of some of these fruit trees at the sites studied (Figure 5). The best represented are olive trees and date palms. Olive wood charcoal comprises more than half of the assemblages (in number of remains and frequencies) at Bosra and Dharih. It appears sporadically from the Early Nabataean at Ez Zantur and only during the Classic Nabataean at Hegra. The date palm is noted at Dharih during the Classic Nabataean, but is especially present at Hegra where the number of remains and its frequency increase through time. The detailed anatomic study of the fragments for this taxon shows that all of the plant parts are present: leaf, central axis of the leaf (rachis) and external and internal parts of the trunk (Bouchaud et al., 2012). Grapevine wood charcoal is present in around 25\% of the samples at Bosra and in less than 5\% of those from Dharih during the Nabataeo-Roman period. Fig trees are found in low proportions at Dharih and Ez Zantur during the Classic Nabataean and pomegranate wood appears at Dharih during the Nabataeo-Roman period and at Hegra in all three periods.

\section{Oil and textile plants}

The class of technical plants includes two taxa: flax (Linum cf. usitatissimum), represented by two seeds at Bosra during the Nabataeo-Roman period and cotton (Gossypium sp.), appearing at the same period at Hegra (Figure 3). Both plants are still used for their textile fibers, from flax stems and cotton seeds, and for oil from their seeds (Reis et al., 2006). Without clear distinctive criteria, identification to the species for cotton is not possible and may correspond to Gossypium arboreum, a species domesticated in northern India and largely cultivated since at least the $3^{\text {rd }}$ millennium on the Indian sub-continent (Fuller, 2008), or to Gossypium herbaceum, a second cotton species probably domesticated in Africa that seems to have been increasingly cultivated in northeast Africa during Antiquity (Bouchaud et al., 2011; Palmer et al., 2012).

\section{Condiments}

Finally, coriander (Coriandrum sativum) is the only condiment plant, potentially cultivated, found and it is represented by two fruit remains in the Nabataeo-roman levels at Bosra (Figure 3).

Correspondence analysis was carried out on the estimations of abundance (see details in the Methods section) for the taxa represented in at least half of the carpological assemblages considered, which excludes the Early Nabataean period at Hegra where sample size is too small $(\mathrm{MNI}<100)$. The dataset thus includes eight objects (site/period assemblages) and nine variables (barley, free-threshing wheat, unidentified cereals, lentil, unidentified pulses, fig, olive, date, grape). The analysis (Figure 4) shows a high contribution on the two first axes (80.59\%) for which the gradient reflects ecological dynamics. The negative part groups the Mediterranean fruit trees (especially olive tree and grapevine), lentils and the three periods of Ez Zantur, and the positive part associates the two periods of occupation at Hegra with the date palm. 


\section{DisCUSSION}

The archaeobotanical analysis of four sites in the southern Near East, occupied during the Nabataean and Roman periods, allows new hypotheses to be proposed regarding the agrarian economy during these periods. First, some general considerations can be made. The first is that all of the plants discussed suggest the presence of agrosystems typified by mixed crops of annual species (cereals, pulses) and perennial fruit trees, the first forms of which were established during the Bronze Age in the Near East (Tengberg, 2012b). This allows confirmation that the population living in the studied region at the $2^{\text {nd }}$ century $\mathrm{BC}$ was based on, or themselves mastered agrarian techniques inherited from the preceding periods. This remark is also based on animal husbandry practices focusing mainly on ovicaprines, camels, pigs, and horses (Studer, 2007). This fits in well with the idea of a mixed economy reflected by the coexistence of nomadic people - probably partly involved in husbandry practices and sedentary agrarian populations (Hopkins 2003; Palmer 2001). In addition, the carpological and anthracological assemblages from sites where diachronic information is available (Dharih, Ez Zantur, Hegra) change little qualitatively between the $2^{\text {nd }}$ century $\mathrm{BC}$ and the $3^{\text {rd }}$ century $A D$, suggesting continuity in practices despite political changes that occurred in the region. Cotton, appearing in Hegra during the Nabataeo-Roman period, is the only taxon demonstrating the existence of a form of innovation, just as it is the only notable element outside the basic economic food systems. In this way, the link between the presence of this nonindigenous plant in the region and the commercial practices of Nabataean populations, mostly described in Greek and Roman texts, should be questioned.

\section{Different productions adapted to climatic and topographic conditions}

The archaeobotanical results agree with the archaeological data and historical sources that identify the four sites as production sites. Cross-interpretation of these results allows us to precisely understand the different types of plant production. These results can then be compared with carpological results from other studies in the region (Table 5). Among these, few concern sites with Nabataean civilization. Most concentrate on Petra and correspond to domestic (Ramsay and Bedal, 2015), funerary (Sachet et al., in press) or religious sectors (Tholbecq et al., 2008). In addition, some elements from the Nabataeo-Roman period were found at Udruh (Neef, 1987), Humayma (Ramsay, 2013), and at the religious site of Tannûr not far from
Dharih (Wetterstrom, 2013). No site near to and contemporaneous with Hegra has been the subject of a published archaeobotanical study ${ }^{11}$.

\section{Crop production and irrigation practices}

The question of irrigation should be addressed before discussing in more detail the agrarian production practices developed at each site. This issue is not difficult for Hegra, where arid conditions prevented any form of rainfed agriculture. Crop irrigation at this site was probably ensured during the Nabataean period, and perhaps earlier using wells ${ }^{12}$ exploiting the water table and defining an important irrigated area around the residential center of the city (Courbon, 2008). At the other three sites, the situation is less clear because climatic conditions could have allowed rainfed agriculture for some productions, even more so if one accepts the hypothesis of a more humid period during the first centuries AD (Leroy, 2010; Rambeau, 2010: 5229). Water collection (basins, cisterns) and water circulation systems are known during the Antique period at Bosra (Braemer et al., 2009), Dharih (Bossut, 2010) and Petra (Bellwald, 2006; Al-Muheisen, 1990, 2009: 42-57) and it is possible that part of these systems were destined for crop irrigation (Nasarat et al., 2012: 108). The presence of irrigated gardens at Petra is moreover pointed out by Strabo at the end of the $1^{\text {st }}$ century BC (Geographica XVI. 4. 21) and by the archaeological evidence of a monumental garden in the center of the city between the end of the $1^{\text {st }}$ century BC and the end of the $3^{\text {rd }}$ century AD (Bedal et al., 2011, 2013). At this site, structures linked to water management seem to have been developed only during the $1^{\text {st }}$ century $\mathrm{BC}$ and especially in the $1^{\text {st }}$ century $\mathrm{AD}$, thus raising the question of the presence or not of irrigated agrarian systems for the Early Nabataean. However, it is useful to balance an interpretation that is based only on archaeological structure to account for the existence or not of crop irrigation practices. Like modern examples, showing for example cereal crops in wadi beds (Palmer, 2001) or the temporary and manual creation of adduction canals dug in the ground, farmers working at these sites certainly had recourse to such ephemeral and barely discernible practices. The study of weed plants at Bosra (Bouchaud, 2012) and Petra (Bouchaud et al., in prep.) shows that some could have developed on wet land, but it is not possible to associate these weeds with a

11. Archaeobotanical remains from the site of Taymâ, north of Hegra, are currently being studied (R. Neef, DAI, Berlin). The site was mainly occupied during the Bronze and Iron Ages, but also contains some Nabataean occupations.

12. The precise dating of wells has not yet been a specific focus of study, but construction techniques allow evaluation of their certain antiquity. 


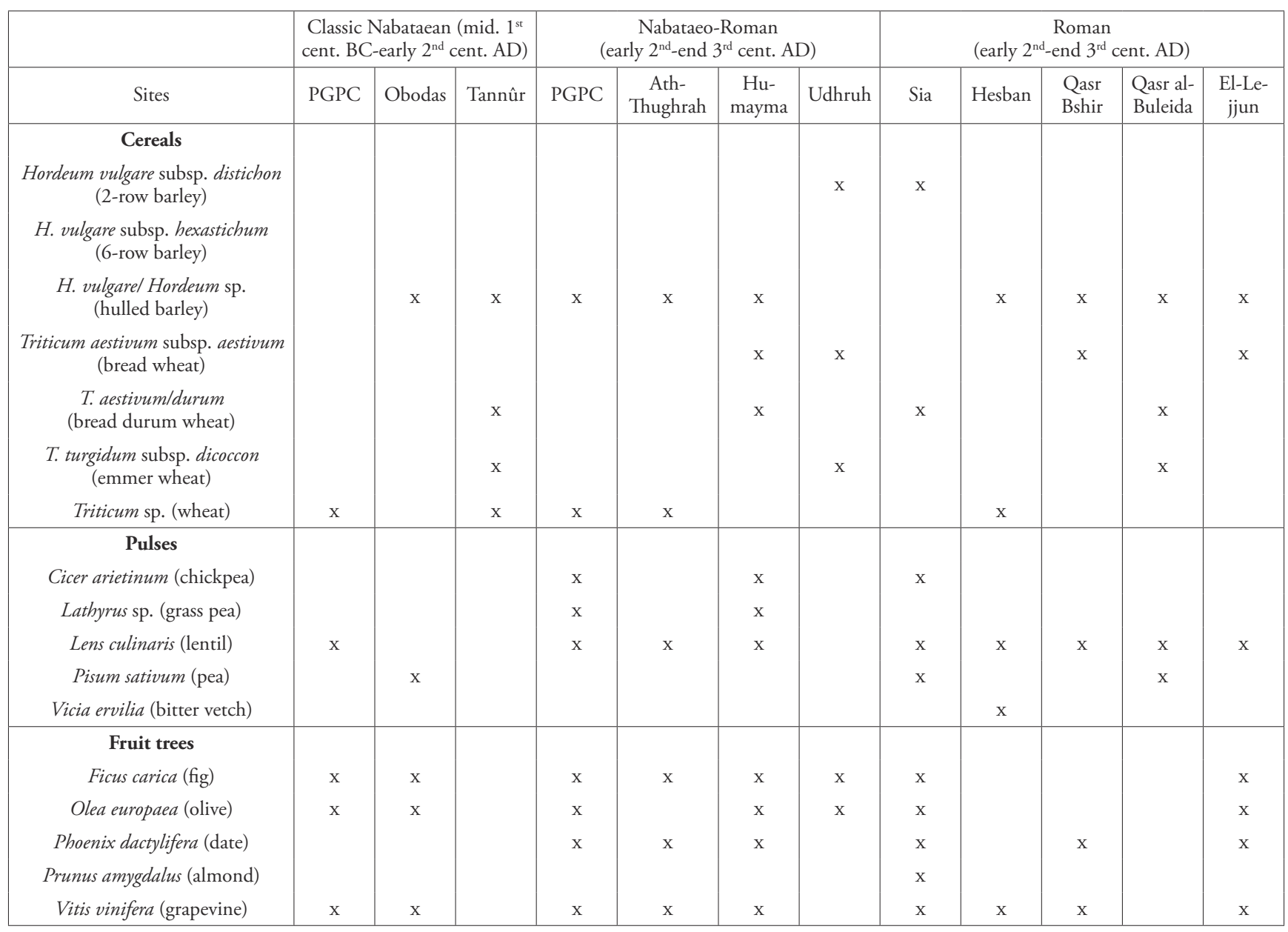

Table 5: Qualitative results for carpological studies at sites in the study region. All the plant remains are preserved by carbonization. PGPC = Petra Garden Pool Complex. Bibliography: PGPC (Ramsay \& Bedal 2015), Obodas, Petra (Bouchaud 2011: 198-202; Tholbecq et al. 2008), Tannûr (Wetterstrom 2013), Ath-Thughrah, Petra (Sachet et al. sous presse), Humayma (Bedal 2013), Udhruh (Neef 1987), Sia (Willcox 2003), Hesban (Gilliland 1986), Qasr Bashir, Qasr al-Buleida, El-Lejjun (Crawford 2006).

Tableau 5: Résultats qualitatifs des études carpologiques menées sur les sites de la région étudiée. Tous les restes végétaux sont conservés par carbonisation. PGPC = Petra Garden Pool Complex. Bibliographie: PGPC (Ramsay \& Bedal 2015), Obodas, Petra (Bouchaud 2011: 198-202; Tholbecq et al. 2008), Tannûr (Wetterstrom 2013), Ath-Thughrah, Petra (Sachet et al. sous presse), Humayma (Bedal 2013), Udhruh (Neef 1987), Sia (Willcox 2003), Hesban (Gilliland 1986), Qasr Bashir, Qasr al-Buleida, El-Lejjun (Crawford 2006).

specific crop given their sole presence in disposal contexts resulting from several activities (Charles et al., 2003). In the absence of direct markers in the archaeobiological data used, we consider the probably concomitant existence of rainfed crops and minor irrigation practices in Bosra, Dharih and Petra, with maybe more important ones for crops requiring regular watering, as grapevine.

\section{Cereals}

By-products of cereal harvests (straw and chaff) are generally considered as pertinent markers of local crops (Van der Veen, 1999). They are present at the four sites. The low pre- sence of these kinds of remains at Ez Zantur in the Classic Nabataean and Nabataeo-Roman levels (Figure 3) clearly indicates that cleaned grain arrived in this residential zone, but archaeological data (Kouki, 2013; Tholbecq, 2013) and ethnographic data (Russell, 1995) suggest the existence of cereal fields not far from the terraces of Ez Zantur. Each of the sites produced barley and durum wheat, two cereals identified as important at the other sites studied in the region. We note that bread wheat (Triticum aestivum subsp. aestivum) is absent in our samples although it was used during the Late Roman period at Roman military sites on the edges of the Jordanian steppe (Crawford, 2006), 
and frequently appear during Early Byzantine, Byzantine (Ramsay \& Smith II, 2013) and Islamic periods ${ }^{13}$ in the region. These initial observations show the probable existence of practices of crop selection that should be identified by a more complete study on the status of free-threshing wheat during Antiquity in the Near East. Emmer wheat the dominant crop in the Near East between the Neolithic and the Bronze Age (Zohary et al., 2012: 41-45) - plays a minor role in the assemblages studied, confirming its secondary presence during this period in the region. In this view, it is of interest to point out its dominant presence in relation to free-threshing wheat at the religious site of Tannur (Wetterstrom, 2013), where it seems to have been used as a plant offering, perhaps highlighting the particular status of this ancient cereal during Antiquity.

Barley, durum wheat and emmer wheat are all winter crops, planted at the start of the rainy season and reaching maturity in spring or early summer. The systematic presence of cereal upper part of root fragments at the four sites indicates that at least part of the harvest was uprooted by hand, a practice still found today among Bedouin populations near Dharih (pers.obs.) and Petra (Simms \& Russell, 1997). It has been experimentally observed that harvesting with a sickle also produces a percentage of uprooted plants at some sites, (Willcox, 2003), but the strong presence of remains at some sites, such as Bosra, leads us to retain the hypothesis of uprooting by hand. Such practices of uprooting may in part explain the small number of reaping tools found for these periods (see for example Crawford, 2006: 459). As cereals represent basic food products for humans and animals and are generally used as fuel, temper, bedding in these semiarid and arid zones (Van der Veen, 1999), they necessarily constitute major annual crops at these production sites. Like neighboring sites (Crawford, 2006), barley seems to have been used in higher proportions than durum wheat, apart from at Hegra where the pattern is slightly reversed.

The identification of two dominant species during the Nabataean and Roman periods could give the impression of homogeneity in cereal production across a large territory. However, this erroneous view should be qualified by a more probable view of an agrobiodiversity dynamic characterized by natural hybridization and the local selection of adapted varieties ("ecogeographic landraces") (Russell, 1995: 696) that the archaeobotanical morphological analysis has diffculty in elucidating.

13. Bread wheat rachis have been identified in the medieval levels at Bosra and Dharih.

\section{Pulses}

No direct element allows confirmation of local pulses crops (as stem or pod elements), except that the range of species recovered shows growth requirements adapted to local climatic conditions. We thus consider that the pulses found at each of the sites were grown locally. The predominance of lentil at all four sites is also observed at other regional sites with carpological data (Table 5). Chickpeas, although well adapted to the semi-arid conditions typical of the southern Near East (Butler, 1998), are present but not common. This observation has led some researchers to see a taphonomic bias (Willcox, 2003) or a consequence of the preparation process of chickpeas that pulverizes the seeds (Crawford 2006). The hypothesis of low use of chickpea is also viable. Studies in the eastern Egyptian desert show, for example, that this crop appears to have truly developed only during the Islamic period, like the other dietary components so characteristic of modern Near Eastern cuisine, including the fava bean (Van der Veen, 2011: 145-149).

\section{Fruit trees}

While some fruit species, particularly the three Mediterranean fruit trees - fig tree, olive tree and grapevine -naturally extend north and west of the region studied (Zohary et al., 2012: 119, 123, 129), the already long history of their cultivation during this period in the region leaves no doubt as to their cultivated status (Tengberg, 2012b). The concomitant presence at a site of fruit remains (seeds, stones) and vegetative elements (leaves, trunk, etc., Table 6) of a single taxon is a reliable criterion generally used to demonstrate local production from fruit trees (Figueiral et al., 2010; Tengberg, 2012b: 183). The hypothesis of local exploitation of some fruit trees, especially olive trees and grapevines, finds support from archaeological field data showing the presence of structures in line with their transformation during Antiquity (Table 6). Basins cut into the rock and areas devoted to grape crushing, probably dating to the Antique period, have been found at Bosra (DentzerFeydy et al., 2007, p. 323) and in the surrounding region (Zerbini, pers. comm.); two olive crushers and presses were found in the Nabataeo-Roman layers at Dharih (Villeneuve, 1990) and rocky pits and basins located just outside the village have been interpreted as remains of a press that could have been used during the Nabatean period (Bossut, 2010, p. 124-125); a round rotary olive crusher was found in the layers at Ez Zantur, dated to the end of the $2^{\text {nd }}$ centuryearly $1^{\text {st }}$ century BC (Kolb \& Keller, 2001, p. 29-30), confirming the existence of an olive oil industry during the Early Nabataean, within the city of Petra itself. Outside Petra, 
many rock installations highlight the probable development of vine-growing activity in the region during the $1^{\text {st }}$ century AD ('Amr et al., 1998, p. 506; Al-Muheisen, 1990, p. 209210). At Hegra, no evidence for olive (or vine-growing) activity has as yet been found, regardless of the occupation period considered, and archaeobotanical remains are the only evidence of the presence of these fruits consumption at the site.

Taking into account that the presence of at least two indices out of three (carpological, anthracological and archaeological data) support local production, it is thus certain that grapevine was grown at Bosra, Dharih and Ez Zantur at least since the Classical Nabataean period. The absence of grapevine charcoal at Ez Zantur may be due to low sampling or lack of use of this wood as fuel. Similarly, the presence of grape seeds alone at Ez Zantur in the early layers perhaps suggests the start of grapevine production at Petra where material evidence is still rare in archaeological studies. Olive tree growing is clearly demonstrated from the Early Nabataean at Petra, for the Nabataean period at Dharih, and is also visible at Hegra during the NabataeoRoman period. For this last site, it has been shown that the fruits, found in specific contexts, may have been reserved for a limited part of the population (Bouchaud, 2013: 14). Date palm production is known at Hegra for all of the occupation periods (Bouchaud, 2013; Bouchaud et al. 2012). Finally, fig production is known at Dharih and Ez Zantur during the Nabataean period and pomegranates at Hegra during the Classical Nabataean.

These assertions are, however, less evident to demonstrate when only one of the archaeobiological signals is detected (Table 6). These differences may be due to several factors, principally linked to 1) the importation of one part of the plant to the site 2) the mode of consumption and use ${ }^{14} 3$ ) taphonomic processes and 4) sampling bias. For the first case, the taxa are represented in form of wood charcoal, but absent in carpological spectra; this can be seen for the date palm at Dharih and olive trees at Bosra. Their presence as charcoal in domestic contexts probably results from their use as fuel after horticultural processing. One could logically infer that the date palm was a limited crop at Dharih and that the lack of date stones is likely directly linked to low sampling. The lack of olive pits in the waste layers at Bosra is more difficult to interpret because sampling was done systematically in the sector studied and this type of remain is typically well-preserved in the charred assemblages. The archaeological excavations at Bosra have not yielded structures linked to olive

14. This kind of explanation may generally explain the very low number of pomegranate seeds, which are typically eaten and entirely digested, and thus less likely to be found in waste assemblages. processing activities. The hypothesis retained (detailed in Bouchaud, 2012, p. 18) proposes the existence of small-scale olive production in villages dispersed on the Hauran Plateau, with little or no material evidence in the archaeological record (Dentzer, 2003; Gentelle, 1985; Villeneuve, 1985: 125), and redistribution of brushwood to Bosra where fuel demand was probably high and firewood rare.

For the second case, the plants are present in form of seeds or fruits, but absent in anthracological spectra, seen for the fig (at Bosra, Ez Zantur and Hegra), the date (at Bosra and Ez Zantur) and grapes (at Ez Zantur and Hegra), for which we have already proposed hypotheses. Some of these fruits were probably imported to consumption sites, such as dates at Bosra, since the climatic conditions there were not conducive to growing this plant (Tengberg, 2012a). This hypothesis is less likely for the dates at Ez Zantur because, like Dharih, some date palms could have been grown along the ephemeral riverbed, as can be seen today, and the lack of charcoal is once again more likely due to method bias. The date stones found in the Nabataean and Roman occupation layers of the Petra Garden and Pool Complex (Table 5), not far from Ez Zantur, show the regular presence of the fruits in the city (Ramsay \& Bedal, 2015). Dried figs are easily transportable products and their presence may evidence such movement, although this not in keeping with the idea of refuse that the presence of charred seeds suggests. At least one element supports the local growing of figs at Bosra during the period immediately following that studied. An epigraphic inscription from the mid- $4^{\text {th }}$ century $\mathrm{AD}$, found in a context of re-use in the city, refers to the reputed quality of the figs of the city (Sartre 1982, IGLS, fasc. XIII. $1, n^{\circ}$ 9439). Finally, the few grape seeds at Hegra are at present the only evidence of their consumption at the site during the Nabataeo-Roman period and the question of the status - locally grown or imported - remains open.

As has been said for the cereals, our view of the presence of only a few visible species of fruits in the archaeobotanical assemblages should be completed by the more accurate one of complex and micro-local agrobiodiversity of fruit tree productions. This is in particular illustrated by the morphometric study done in Nabataeo-Roman grape seeds at Ez Zantur. This study shows very clearly the complex interactions between the plant and human populations by highlighting the likely presence of several cultivars, including some with a morphology similar to wild grapevines (Jacquat \& Martinoli, 1999).

\section{Agrosystems dynamics}

The distribution of cereal, pulses and fruit trees production systems at the four sites demonstrates the existence of 
two types of agrosystems that clearly respond to climatic limitations. A split is observed between sites with a semiarid climate (Bosra, Dharih and Ez Zantur) where precipitation was sufficient to allow rainfed agriculture for some of the crops and Hegra, which has an arid climate where crop irrigation was required. This split can be seen by the distribution of fruits (Figure 4): Mediterranean (olives, grapevines, figs) to the north, date palms at Hegra, while cereals and pulses are, with a few exceptions, identical. These associations of annual crops and fruit trees reflect the known models of traditional Mediterranean agroforestry systems (Eichhorn et al., 2006) and oasis agrosystems (Battesti, 2005; Tengberg, 2012a), offering an adapted and durable response to environmental constraints while ensuring economic autonomy. The range of annual crops includes plants generally sown at the beginning or middle of winter and grown during the rainy season. Chickpeas are a summer crop (planted in spring or the beginning of summer) but today it grows in Jordan without being irrigated (Palmer, 2001). At Bosra, Dharih and Petra, it is thus possible that the production of these annual crops could have been done without a supplementary water supply, as this is still the case in the modern and contemporary periods (Delbet, 1877; Palmer, 2001; Russell, 1995) except perhaps in years where precipitation was too irregular and insufficient to ensure their growth. Biennial rotation (usually fallow-cereal but also legume-cereal) is the most commonly used practice in the semi-arid regions. In the driest areas, or years, no strict rotation is observed and cereals are sown every time there is deemed to be sufficient rain. Cultivated fallow restore humidity to the land and fertilize it, notably by its use as pasturage for animal herds (Palmer 1997, 1998, 2001). The use of this system at each of the sites studied leaves little doubt, fully illustrating the complementarity that must have existed between agricultural and pastoral activities. The archaeobotanical results demonstrate the importance of fruits in the ancient economic systems, whether in oasis or semiarid environments. In the latter, some of these perennial crops, particularly grapevines, would probably have been irrigated. According to modern traditional agroforestry system (Eichhorn et al., 2006), we can postulate that part of these perennial fruit plants grew on the same fields than annual crops. Such complementarity between the different activity sectors is also expressed by the important role of secondary agricultural products, both in the carpological and anthracological assemblages. These elements - chaff and straw recovered after cereal harvest, branches, leaves and deadwood obtained during maintenance of fruit trees - had an important role in these regions where wood was limited. They could have been used both for the fuel eco- nomy, thus explaining in large part their strong presence in the charred assemblages (Bouchaud, 2014), and for bedding and auxiliary fodder. This view assumes the complex management of all available resources and the circulation of products between the different centers of activities within and around the cities and villages studied. On this basis, the use of dung as fuel is suggested at all of the sites studied (Bouchaud, 2012, 2013; Jacquat \& Martinoli, 1999) and can in part explain the presence of plant remains in the charred assemblages.

The disparity between the number of samples and remains makes quantitative comparisons between sites and periods difficult and the interpretations made should be reevaluated in the light of future data that will be acquired in this region. In the current state of our research, the data suggest a high geographic discrimination, perhaps revealing a form of specialization in production in relation to local topographic and climatic conditions. Thus the presence of cereals compared to other cultivated remains is highest at Bosra (Figures 2, 4), olives are the major crop on the semi-mountainous limestone slopes of Dharih and Petra and the date palm is dominant at Hegra (Figures 3, 4, 5). The sites with diachronic information (Dharih, Ez Zantur, Hegra) show that the presence of these fruit trees - olive and date palm - increases through time (Table 6). While these estimations cannot be expressed in production numbers, they agree well with the hypotheses formulated using field data, essentially available for Petra, showing an increase in exploited areas over the $1^{\text {st }}$ century AD (Kouki, 2009; Tholbecq, 2013). Although these data maybe suggest phenomena of specialization and increase in production, they don't show directly the development of production goods for economic trade that is supposed to characterize the Nabataean civilization.

\section{Innovation in the Nabataean territory}

\section{Absent species}

Comparison of written sources mentioning Nabataean agricultural production and archaeological data highlights significant discrepancies. Two major elements probably explain in large part these divergences: the first is that the written sources come from the Greco-Roman world and their veracity should naturally be questioned; the second is that the preservation of plants by carbonization drastically limits the list of plants susceptible of being preserved in the archaeological deposits (Van der Veen, 2007). A few of the most relevant comparisons can be provided here. The first comes from Strabo, who states that olive oil as not produced in the Nabataean territory, where it was replaced by sesame oil (Geo. XVI.4.26). The archaeobotanical results showing 
the omnipresence of olives, along with discoveries of olive crushers and presses, clearly allows rejection of the first part of his assertion. In contrast, the reference to the use of sesame finds support from the chemical analysis of the contents of liquid containers found at Petra (Garnier $e t$ al., 2011). This element does not enable confirmation of sesame production in the Nabataean territory, but it is possible that sesame oil or seeds, known in the Near East since the $5^{\text {th }}$ millennium (Zohary et al., 2012: 112-113), could have been traded. The absence of sesame seeds in the sediment samples from Ez Zantur and other zones of Petra that were subject to an archaeobotanical analysis (Table 6) is thus likely rather due to a preservation problem or because sesame was only available in Petra as oil. This may also be true for flax, which is only weakly represented in the carpological assemblages of Bosra, although we know that this plant was exploited for textiles since the Neolithic in the Near East (McCorriston, 1997; Zohary et al., 2012: 103-104) and that the linen textiles were used by Nabataean populations (Bouchaud et al., in press; Granger-Taylor, 2000; Lenoble et al., 2001). The use of flax fibers, which generally requires the plant to be cut before going to seed (Reis et al. 2006), and the fact that the fibers react poorly to carbonization limits the representativeness of flax although it had a non-negligible part in the economic systems.

\section{Commerce and emergence of cotton}

Cotton seeds at Hegra are the only significant and tangible evidence demonstrating the presence of a new plant element in the Nabataean territory. The frequency and distribution of seeds in the residential sector of the city of Hegra and the context of these discoveries in the spatio-temporal dynamics of the spread of this plant support the hypothesis of local cotton production (Bouchaud et al., 2011). A crop requiring light and heat reaching maturity at the end of summer, cotton appears to have spread across the Arabian Peninsula and Egypt during Antiquity only in oasis agrosystems. These form environments efficiently meeting the ecological needs of the plant (Bouchaud et al., 2011). Cotton is thus a textile source accessible in Nabataean territory, probably alongside flax and wool, although the relative importance of its use cannot as yet be measured. This is very likely to be fairly low, if we judge by the low number of pieces of cotton found in contexts yielding archaeological textiles (Bouchaud et al., 2011; Granger-Taylor, 2000). However, this new production shows the willingness to locally produce a plant offering a non-dietary product that would, moreover, have been available through the distribution circuits in which the Nabataeans were integrated. Indian cotton cloth is, for example, one of the products mentioned in Periplus Maris Erythraei, a manual written in the $1^{\text {st }}$ century AD for merchants involved in commercial trade between Egypt

\begin{tabular}{|c|c|c|c|c|c|c|c|c|c|c|c|c|c|c|c|c|}
\hline \multirow[b]{3}{*}{ Ficus carica } & \multirow{2}{*}{\multicolumn{2}{|c|}{$\frac{\text { Bosra }}{100-300 \mathrm{AD}}$}} & \multicolumn{3}{|c|}{ Dharih } & \multicolumn{5}{|c|}{ Ez Zantur } & \multicolumn{6}{|c|}{ Hegra } \\
\hline & & & \multicolumn{2}{|c|}{ 50-100 AD } & \multirow{2}{*}{$\begin{array}{l}100- \\
300 \\
\mathrm{AD}\end{array}$} & \multicolumn{2}{|c|}{$150-50 \mathrm{BC}$} & \multicolumn{2}{|c|}{$50 \mathrm{BC}-100 \mathrm{AD}$} & \multirow{2}{*}{$\begin{array}{l}100- \\
300 \\
A D \\
\bullet \bullet \bullet\end{array}$} & \multicolumn{2}{|c|}{$200-50$ BC } & \multicolumn{2}{|c|}{$50 \mathrm{BC}-100 \mathrm{AD}$} & \multicolumn{2}{|c|}{$100-300 \mathrm{AD}$} \\
\hline & $\bullet \bullet$ & & $\bullet \bullet$ & $\Delta 00$ & & $\bullet \bullet$ & & $\bullet$ & $\Delta \Delta$ & & $\bullet \bullet$ & & $\bullet$ & & $\bullet$ & \\
\hline $\begin{array}{c}\text { Phoenix dac- } \\
\text { tylifera }\end{array}$ & $\bullet$ & & & 000 & & $\bullet$ & & $\bullet$ & & & $\cdots$ & $\Delta 000$ & $\bullet \bullet$ & $\Delta 000$ & $\bullet \bullet \bullet$ & $\Delta \Delta \Delta 0$ \\
\hline Punica granatum & & & & & $\Delta \Delta$ & & & & & & & $\Delta \diamond \diamond$ & & $\Delta \Delta$ & $\bullet$ & $\Delta$ \\
\hline Olea europaea & & $\Delta 0 \Delta 0$ & $\cdots$ & 0000 & 0000 & $\bullet$ & $\Delta\rangle$ & $\cdots$ & $\Delta \diamond \diamond$ & $\cdots$ & & & & $\Delta \diamond$ & $\bullet$ & $\Delta$ \\
\hline Vitis vinifera & $\bullet$ & $\Delta 00$ & $\bullet$ & & 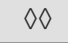 & $\bullet$ & & $\cdots$ & & $\bullet \bullet$ & & & & & $\bullet$ & \\
\hline
\end{tabular}

Table 6: Representativeness of fruit taxa in the carpological and anthracological assemblages. The estimations are based on frequencies. The gray squares indicate the presence of archaeological structures evidencing olive or grape processing activities.

\begin{tabular}{|l|c|c|c|c|}
\hline Frequency & $<2 \%$ & $2-15 \%$ & $15-50 \%$ & $>50 \%$ \\
\hline$\bullet=$ carpological remains & $\bullet$ & $\boldsymbol{\bullet}$ & $\boldsymbol{\bullet \bullet \bullet}$ & $\boldsymbol{\bullet . \bullet}$ \\
\hline$\diamond=$ anthracological remains & $\diamond$ & $\diamond \diamond$ & $\diamond \diamond \diamond$ & $\diamond \diamond \diamond \diamond$ \\
\hline
\end{tabular}

Tableau 6 : Représentativité des taxons fruitiers dans les assemblages carpologiques et anthracologiques. Les estimations sont faites à partir des fréquences d'attestation. Les carrés grisés indiquent la présence de structures archéologiques témoignant d'activités oléicoles ou viticoles.

\begin{tabular}{|l|c|c|c|c|}
\hline Frequency & $<2 \%$ & $2-15 \%$ & $15-50 \%$ & $>50 \%$ \\
\hline$\bullet=$ restes carpologiques & $\bullet$ & $\bullet$ & $\bullet$ & $\cdots$ \\
\hline$\diamond=$ restes anthracologiques & $\diamond$ & $\Delta \diamond$ & $\Delta \diamond \diamond$ & $\Delta \Delta \Delta \diamond$ \\
\hline
\end{tabular}


and the Indian sub-continent (Casson, 1989). It is highly probably that the Nabataeans also had access to these products through their trade activities with Arabia felix and they could have even played a role in the distribution of cotton textile along the Incense Road. Based on the radiocarbon dates (Table 2), we note that cotton production at Hegra appears at the earliest at the end of the $1^{\text {st }}$ century or early $2^{\text {nd }}$ century $\mathrm{AD}$, that is, during an important period of political transition for the Nabataean kingdom. Hegra, located on the edge of the kingdom, does not, however, seem to have taken in a sizable Roman population (Villeneuve, 2014) and it thus appears improbable that this agricultural innovation would be linked to a Roman political will. In contrast, it more likely illustrates a local risk-taking by part of the population wanting to exploit a new product that could serve as a marketable commodity. Modes of introduction for this plant, assuming the acquisition of new agricultural and craft knowledge, remain to be discovered. With regard to current data, two hypotheses can be proposed. One consists of seeing the emergence of commercial trade with the Indian sub-continent, possibly by the intermediary of the Persian Gulf (Durand \& Gerber, 2014), or the southern Arabia. The other is based on the fact that cotton in Arabia appears at the same time as the development of its culture in Egypt. In this case, its presence could be evidence of trade between Egypt and Arabia Petraea, trade that is also seen in the presence of Nabataean graffiti on the eastern desert routes (Durand, 2012). These cotton finds, either Indian or African origin, highlight the adoption of one particular good formerly only available thanks to the long-distance trade roads and show a diversification process of potential trade products in the Nabataean territory under the Roman domination.

\section{Conclusion}

The combined approach using carpological and anthracological data alongside other archaeological and written sources furthers our understanding of the economic systems in place in the Nabataean territory while at the same time contributing new data. The disparity of the quantitative results limits, however, an interpretation that should be refined using more systematic archaeobotanical studies at the sites excavated. The results show that the plant resources exploited in the region are varied and well adapted to climatic and topographic conditions, creating agrarian territories with strong local identities. The existing agrosystems were directly inherited from preceding periods, underlining the permanence of practices between the Bronze and Iron Ages and the Nabataean period. The association of annual and perennial crops enabled an efficient response to dietary, technical and combustible needs, and clearly shows a complex mode of exploitation and distribution of resources between the different economic centers at a single site. In parallel to these proven forms of polyculture, the distribution of data may show trends toward production specialization, as well as the development of agrarian production over time. Finally, the carpological analysis sheds light on a process of agrarian innovation by the appearance of cotton growing at Hegra at the end of the $1^{\text {st }}$ century or the beginning of the $2^{\text {nd }}$ century $\mathrm{AD}$, a phenomenon probably attributable to the commercial activities in the region.

\section{Acknoledgements}

I warmly thank the archaeologists responsible for the missions at Bosra (P.-M. Blanc, French Mission of Southern Syrira, dir. F. Braemer), Dharih (F. Villeneuve and Z. Al-Muheisen), Ez Zantur (R.A. Stucky, B. Kolb) and Hegra (L. Nehmé, F. Villeneuve, D. al-Talhi), and the archaeobotanists who previously worked at Bosra (G. Willcox) and Ez Zantur (Ch. Jacquat) for having entrusted me with the analysis of the plant remains. I also thank Laila Nehmé and François Villeneuve for their relevant re-reading, Rebecca Miller for the English translation, and the two anonymous reviewers for their useful remarks. Finally, I would like to express my sincere thanks to the members of the GMPCA for awarding a thesis prize that allowed the writing of this article.

\section{Bibliography}

Al-Muneisen Z., 1990. Exemples d'installations hydrauliques et des techniques d'irrigation dans le domaine nabatéen (Pétra, Jordanie méridionale). In B. Geyer (ed.). Techniques et pratiques hydro-agricoles traditionnelles en domaine irrigué. Approche pluridisciplinaire des modes de culture avant la motorisation en Syrie. Paris, P. Geuthner, 507-511.

Al-Muheisen Z., 2009. The Water Engineering and Irrigation System of the Nabataeans. Yarmouk University, Irbid.

Nasarat M., Danah F. A., Naimat S., 2012. Agriculture in sixthcentury Petra and its hinterland, the evidence from the Petra papyri. Arabian Archaeology and Epigraphy, 23: 105-115.

Al-TAlhi D., Al-Daire M., 2005. Roman presence in the desert. A new inscription from Hegra. Chiron, 35: 205-217.

'Amr K., Al-Momani A., Farajat S., Falahat H., 1998. Archaeological survey of the Wadi Musa water supply and wastewater project area. Annual of the Department of Antiquities of Jordan, 42: 503-548. 
Battesti V., 2005. Jardins au désert: évolution des pratiques et savoirs oasiens: Jérid tunisien. Paris, IRD editions.

Bedal L.-A., Convers L. B., Foss J. E., Gleason K. L., 2013. The Petra Garden and Pool Complex. Ma'an, Jordan. In A.-A. Malek (ed.). Sourcebook for garden archaeology: methods, techniques, interpretations and field examples. Bern, P.Lang, 625-641.

Bedal L.-A., Schryver J. G., Gleason K. L., 2011. The Petra Garden and Pool Complex, 2007 and 2009 Field Seasons. Annual of the Department of Antiquities of Jordan, 55: 313-328.

Bellwald U., 2006. The hydraulic infrastructure of Petra. A model for water strategies in arid land. In G. Wiplinger (ed.). Cura Aquarum in Ephesus: Proceedings of the Twelth International Congress on the History of Water Management and Hydraulic Engineering in the Mediterranean Region. Louvain, Peeters Publishers, 225-235.

Besançon J., 2010. Géographie, environnements et potentiels productifs de la région de Pétra (Jordanie). In P.-L. Gatier B. Geyer, M.-O. Rousset (eds.). Entre Nomades et Sédentaires. Prospections En Syrie Du Nord et En Jordanie Du Sud. Paris, De Boccard, 19-71.

Bignasca A., Desse-Berset M., Fellmann Brogli R., Glutz R., Karg S., Keller D., Kolb B., Kramar C., Peter M., Schmid S., Schneider C., Stucky R. A., Studer J., Zanoni I., 1996. Petra Ez-Zantur I. Ergehnisse der schweizerisch-liechtensteinischen Ausgrabungen 1988-1992. Mainz am Rhein, P. von Zabern.

Bossut P., 2010. Prospection au wadi La'ban et étude géographique. Fouilles de Dharih IV. Syria, 87: 115-145.

Bouby L., Marinval P., 2004. Fruits and seeds from Roman cremations in Limagne (Massif Central) and the spatial variability of plant offerings in France. Journal of Archaeological Science, 31: 77-86.

Bouchaud C., 2011. Paysages et pratiques d'exploitation des ressources végétales en milieux semi-aride et aride dans le sud du Proche-Orient: Approche archéobotanique des périodes antique et islamique (IV siècle av. J.-C.-XVI siècle apr. J.-C.). Unpublished doctoral thesis, Paris, Université Paris 1 Panthéon-Sorbonne.

Bouchaud C., 2012. Productions végétales et acquisition du combustible sur le plateau du Hauran : Analyse archéobotanique du chantier BAT de Bosra. In A. Le Bihan P.-M. Blanc F. Braemer J. Dentzer-Feydy, F. Villeneuve (eds.). Territoires, Architecture et Matériel Au Levant. Beyrouth, Presses de l'Ifpo. http://ifpo.revues.org/2939, consulté en 04/2015.

Bouchaud C., 2013. Exploitation végétale des oasis d'Arabie : production, commerce et utilisation des plantes. L'exemple de Madâ'in Sâlih (Arabie Saoudite) entre le Iv ${ }^{e}$ siècle av. J.-C. et le vir ${ }^{\mathrm{e}}$ siècle apr. J.-C. In Tengberg M., Newton C., Battesti V. (éds). "L'arbre sans rival". Palmiers dattiers et palmeraies au Moyen-Orient et en Égypte de la préhistoire à nos jours.
$\mathrm{N}^{\circ}$ spécial de la Revue d'ethnoécologie 4. [http:/lethnoecologie. revues.org/1217], consulté en 04/2015.

Bouchaud C., 2014. Gestion et utilisation des combustibles végétaux dans les structures thermales : Études carpologiques et anthracologiques de cinq thermes des époques byzantines et omeyyades au Proche-orient. In M.-F. Boussac S. Denoix T. Fournet, B. Redon (eds.). Balaneia. 25 Siècles de Bain Collectif En Orient. Proche-Orient, Egypte et Péninsule Arabique. Le Caire, Institut français d'archéologie orientale, 595-609.

Bouchaud C., Jacquat C., Martinoli D., in preparation. Agricultural economy and landscape evolution in Petra (Jordan) from Early Nabataean to Byzantine times ( $2^{\text {nd }}$ century BC-AD $5^{\text {th }}$ century).

Bouchaud C., Sachet I., Dal-Prà P., Delhopital N., Douaud R., Leguilloux M., in press. New discoveries in a Nabataean tomb. Burial practices and "plant jewellery" in ancient Hegra (Madầin Sâlih, Saudi Arabia). Arabian Archaeology and Epigraphy.

Bouchaud C., Tengberg M., Dal Prà P., 2011. Cotton cultivation and textile production in the Arabian Peninsula during antiquity: the evidence from Madâ'in Sâlih (Saudi Arabia) and Qal'at al-Bahrain (Bahrain). Vegetation History and Archaeobotany, 20: 405-417.

Bouchaud C., Thomas R., Tengberg M., 2012. Optimal use of the date palm (Phoenix dactylifera L.) during Antiquity : Anatomical identification of plant remains from Madâ' in Sâlih (Saudi Arabia). In E. Badal (ed.). Wood and Charcoal. Evidences for the Human and Natural History. Valencia, Universitat de Valencia, 173-185.

Bowersock G. W., 1983. Roman Arabia. Cambridge, Harvard University Press.

Braemer F., 2002. Le rempart de Bosra au $\mathrm{II}^{\mathrm{e}}$ millénaire avant notre ère. Syria, 79: 65-74.

Braemer F., Genequand D., Maridat C. D., Blanc P. M., Dentzer J. M., Gazagne D., Wech P., 2009. Long-term management of water in the Central Levant: the Hawran case (Syria). World Archaeology, 41: 36-57.

Butler A., 1998. Grain legumes: Evidence of these important ancient food resources from early pre-agrarian and agrarian sites in southwest Asia. In A. B. Damania (ed.). The origins of agriculture and crop domestication. Alep, International Center for Agricultural Research in Dry Areas, 102-117.

Cappers R. T. J., Neef R., 2012. Handbook of plant palaeoecology. Groningen, Barkhuis.

Casson L., 1989. The Periplus Maris Erythraei. Princeton, Princeton University Press.

Charles M., Hoppé C., Jones G., Bogaard A., Hodgson J. G., 2003. Using weed functional attributes for the identification of irrigation regimes in Jordan. Journal of Archaeological Science, 30 (11): 1429-1441 
Charloux G., 2011. Area 1. In L. Nehmé (ed.). Report on the Fourth Excavation Season (2011) of the Madâin Sâlih Archaeological Project, 25-45.

Courbon P., 2008. Les puits nabatéens de Madâ’ in Sâlih (Arabie Saoudite). Arabian Archaeology and Epigraphy, 19: 48-70.

Crawford P., 2006. The plant remains. In S. T. Parker (ed.). The Roman Frontier in Central Jordan. Final Report on the Limes Arabicus Project 1980-1989. Washington, Dumbarton Oaks, 453-461.

Delbet E. M., 1877. Paysans en communauté et en polygamie de Bousrah (Esky Cham) dans le pays Haouran (Syrie, Empire ottoman). In F. Le Play (ed.). Les Ouvriers de l'Orient, 2. Les Ouvriers de l'Orient et Leurs Essaims de La Méditerranée. Paris, Mame, $2^{\text {de }}$ édition, 304-357.

Dentzer J.-M., 2003. La vigne dans le paysage et la culture de la Syrie du sud. In J. Dentzer-Feydy, J. M. Dentzer, P.-M. Blanc (eds.). Hauran II. Beyrouth, Institut français d'archéologie du Proche-Orient, 163-174.

Dentzer J. M., Dentzer-Feydy J., Blanc P.-M., 2001. Busra dans la perspective par millénaires: la Busra nabatéenne. Studies in the History and Archaeology of Jordan, 4: 457-468.

Dentzer-Feydy J., Vallerin M., Fournet T., Mukdad R., Mukdad A., 2008. Bosra Aux Portes de l'Arabie. Beyrouth, IFPO.

Durand C., 2008. Le rôle des Nabatéens dans le commerce oriental et méditerranéen de l'époque hellénistique aux campagnes de Trajan (IV s. av. J.-C.-II ${ }^{\mathrm{e}}$ s. apr. J.-C.). Étude historique et archéologique. Unpublished Doctoral thesis. Lyon, Université Lumière Lyon 2.

Durand C., 2012. Crossing the Red Sea: the Nabataeans in the Egyptian Eastern Desert. In D. A. Agius, J. P. Cooper, A. Trakadas, C. Zazzaro (eds.). Navigated Spaces, Connected Places. Proceedings of the Red Sea Project V Held at the University of Exeter, 16-19 September 2010. Oxford, Archaeopress, 85-90.

Durand C., Gerber Y., 2014. The pottery production from Hegra/Madâin Sâlih (Saudi Arabia) during the Nabataean period. Preliminary results, 2008-2011. Proceedings of the Seminar for Arabian studies, 44: 153-168.

Eichhorn M. P., Paris P., Herzog F., Incoll L. D., Liagre F., Mantzanas K., Mayus M., Moreno G., Papanastasis V. P., Pilbeam D. J., Pisanelli A., Dupraz C., 2006. Silvoarable Systems in Europe - Past, Present and Future Prospects. Agroforestry System, 67: 29-50.

EL FAÏz M. E., 1995. L'agronomie de la Mésopotamie antique : analyse du "Livre de l'agriculture nabatéenne" de Qûtâmä. Leiden, Brill.

ERICKSON-Gini T., 2012. Nabataean agriculture: Myth and reality. Journal of Arid Environments, 86: 50-54.

Fiema Z. T., 2003. Roman Petra (AD 106-363): A neglected subject. Zeitschrift des deutschen palästina vereins, 119: 38-58.
Figueiral I., Bouby L., Buffat L., Petitot H., Terral J.-F., 2010. Archaeobotany, vine growing and wine producing in Roman Southern France: The site of Gasquinoy (Béziers, Hérault). Journal of Archaeological Science, 37: 139-149.

Fuller D. Q., 2008. The spread of textile production and textile crops in India beyond the Harappan zone: an aspect of the emergence of craft specialization and systematic trade. Linguistics, archaeology and the human past. Indus Project. Kyoto: Research Institute for Humanity and Nature: 1-26.

Garnier N., Tokarski C., Rolando C., 2011. Quels combustibles pour les lampes? Apport des analyses chimiques organiques par chromatographie et spectrométrie de masse. In D. Frangié, J.-F. Salles (eds.). Lampes antiques du Bilad es-Sham : Jordanie, Syrie, Liban, Palestine. Actes du colloque Pétra-Amman, 6-13 novembre 2005. Paris, De Boccard, 103-123.

Gentelle P., 1985. Éléments pour une histoire des paysages et du peuplement du Djebel Hauran septentrional. In J. M. Dentzer (ed.). Hauran I. Recherches Archéologiques Sur La Syrie Du Sud À L'époque Hellénistique et Romaine. BAH n¹24, Beyrouth, Presses de l'IFPO, 19-62.

Gentelle P., 2009. Aménagement du territoire agricole de la ville de Pétra: la terre et l'eau. In M. Al-Dbiyat (ed.). Stratégies d'acquisition de l'eau et société au Moyen-Orient depuis l'Antiquité. BAH n 186 , Beyrouth, Presses de l'IFPO, 133-148.

Gilliland D. R., 1986. Paleoethnobotany and paleoenvironment. In S. LaBianca, L. Lacelle (eds.). Hesban 2. Environmental foundation: Studies of Climatical, Geological, Hydrological, and Phytological Conditions in Hesban and Vicinity. Andrews University Press, Berrien Springs, 123-142.

Graf D., 2007. Nabataeans under Roman Rule (After AD 106). In K. D. Politis (ed.). The World of the Nabataeans. Stuttgart, Steiner-Verlag, 173-186.

Graf D. F., 2013. Petra and the Nabataeans in the Early Hellenistic period: the literary and archaeological evidence. In M. Mouton, S. Schmid (eds.). Men on the Rocks. The Formation of Nabataean Petra, (2-4 December 2011: Berlin). Berlin, Logos Verlag, 35-56.

Granger-Taylor H., 2000. The Textiles from Khirbet Qazone (Jordan). In D. Cardon, M. Feugère (eds.). Archéologie des textiles, des origines au Ve siècle. Montagnac, Monique Mergoil, 149-161.

Grawehr M., 2010. Petra Ez Zantur IV: Ergebnisse der Schweizerisch-Liechtensteinischen Ausgrabungen. Eine Bronzewerkstatt des 1. Jhs. n. Chr. von ez Zantur in Petra, Jordanien. Mainz am Rhein, von Zabern.

Hämeen-Anttila J., 2006. The last Pagans of Iraq: Ibn Wahshiyya and his Nabatean agriculture. Leiden/Boston, Brill.

Hopkins D. C., 2003. Agriculture. In S. Richard (ed.). Near Eastern Archaeology: A Reader. Winona Lake, Eisenbrauns, 124-130. 
JaCQUat C., Martinoli D., 1999. Vitis vinifera L.: Wild or cultivated? Study of the grape pips found at Petra, Jordan, 150 BC-AD 40. Vegetation History and Archaeobotany, 8: 25-30.

Keller D., Grawehr M., 2006. Petra Ez Zantur III: Ergebnisse der Schweizerisch-Liechtensteinischen Ausgrabungen. Mainz am Rhein, von Zabern.

Kolb B., 2003. Petra-From Tent to Mansion: Living on the Terraces of Ez-Zantur. In G. Markoe (ed.). Petra Rediscovered. Lost city of the Nabataeans. Londres, Thames \& Hudson, 230237.

Kolb B., Keller D., 2001. Swiss-Liechtenstein Excavation at azZantur/Petra: The Eleventh Season. Annual of the Department of Archaeology of Jordan, 45: 311-324.

Kouki P., 2009. Archaeological Evidence of Land Tenure in the Petra Region, Jordan: Nabataean-Early Roman to Late Byzantine. Journal of Mediterranean Archaeology, 22: 29-56.

Kouki P., 2013. The intensification of Nabataean agriculture in the Petra region. In M. Mouton, S. Schmid (eds.). Men on the Rocks. The Formation of Nabataean Petra, (2-4 December 2011: Berlin). Berlin, Logos Verlag, 323-333.

Leblanc J., 2007. L'organisation du territoire: les parcellaires. In J. Dentzer-Feydy M. Vallerin T. Fournet R. Mukdad, A. Mukdad (eds.). Bosra Aux Portes de l'Arabie, Beyrouth, IFPO, 319-321.

LeE G. A., 2012. Taphonomy and sample size estimation in paleoethnobotany. Journal of Archaeological Science, 39: 648655.

Lenoble P., Al-Muheisen Z., Villeneuve F., 2001. Fouilles de Khirbet edh-Dharih (Jordanie), I: le cimetière au sud du Wadi Sharheh. Syria, 78: 89-151.

Leroy S. A. G., 2010. Pollen analysis of core DS7-1SC (Dead Sea) showing intertwined effects of climatic change and human activities in the Late Holocene. Journal of Archaeological Science, 37: 306-316.

McCorriston J., 1997. The fiber revolution: Textile extensification, alienation, and social stratification in ancient Mesopotamia. Current Anthropology, 38: 517-549.

Mouton M., Schmid S., 2013. Men on the rocks. The formation of Nabataean Petra, (2-4 December 2011: Berlin). Berlin, Logos Verlag.

Neef R., 1987. Botanical remains. In A. Killick (ed.). Udhruh, caravan city and desert oasis. A guide to Udhruh and its surrounding. Hampshire, Romsey, 16.

Nehmé L., Arnoux T., Bessac J. C., Braun J. P., Dentzer J. M., Kermorvant A., Rigot J. B., Sachet I., TholbecQ L., 2006. Mission archéologique de Madâ'in Sâlih, Arabie Saoudite: Recherches menées de 2001 à 2003 dans l'ancienne Hijrâ des Nabatéens. Arabian Archaeology and Epigraphy, 17: 41-124.

Nehmé L., Villeneuve F., 1999. Pétra: métropole de l'Arabie antique. Paris, Seuil.
Oleson J. P., 2001. Water-supply in Jordan through the Ages. In B. MacDonald, R. Adams, P. Bienkowski (eds.). The Archaeology of Jordan, Sheffield, Sheffield Academic Press, 603-614.

Oleson J. P., 2007. Nabataeans water supply, irrigation and agriculture. In K. D. Politis (ed.). The World of the Nabataeans. Stuttgart, Steiner-Verlag, 217-249.

Oleson J. P., 2010. Humayma Excavation Project, 1: Resources, History, and the Water-Supply System. Boston, American Schools of Oriental Research.

Palmer C., 1997. An Exploration of the Effects of Crop Rotation Regime on Modem Weed Floras. Environmental Archaeology, 2 (1): 35-48.

Palmer C., 2001. Traditional agriculture. In B. MacDonald, R. Adams, P. Bienkowski (eds.). The Archaeology of Jordan. Sheffield, Sheffield Academic Press, 621-629.

Palmer C., 1998. "Following the plough": the agricultural environment of northern Jordan. Levant, 30: 129-165.

Palmer S. A., Clapham A. J., Rose P., Freitas F. O., Owen B. D., Beresford-Jones D., Moore J. D., Kitchen J. L., Allaby R. G., 2012. Archaeogenomic Evidence of Punctuated Genome Evolution in Gossypium. Molecular Biology and Evolution, 29: 2031-2038.

Rambeau C. M. C., 2010. Palaeoenvironmental reconstruction in the Southern Levant: synthesis, challenges, recent developments and perspectives. Philosophical Transactions of the Royal Society A: Mathematical, Physical and Engineering Sciences, 368 : 5225-5248.

Ramsay J., 2013. Plant remains. In J.-P. Oleson, R. Schick (eds.). Humayma excavation project 2. Nabataean campground and necropolis Byzantine churches, and Early Islamic domestic structures. Boston, American Schools of Oriental Research, 351380.

Ramsay J., Bedal L. A., 2015. Garden variety seeds? Botanical remains from the Petra Garden and Pool Complex. Vegetation History and Archaebotany, [http://dx.doi.org/10.1007/s00334015-0520-4], consulté en 04/2015.

Ramsay J., Smith II A. M., 2013. Desert Agriculture at Bir Madhkur: The First Archaeobotanical Evidence to Support the Timing and Scale of Agriculture in the Hinterland of Petra. Journal of Arid Environments, 99: 51-63.

Reimer P. J., Baillie M. G. L., Bard E., Bayliss A., Beck J. W., Blackwell P. G., Bronk Ramsey C., Buck C. E., Burr G. S., Edwards R. L., Friedrich M., Grootes P. M., Guilderson T. P., Hadjas I., Heaton T. J., Hogg A. G., Hughen K. A., Kaiser K. F., Kromer B., McCormac F. G., Manning S. W., Reimer R. W., Richards D. A., Southon J. R., Talamo S., Turney C. S. M., van der Plicht J., Weyhenmeyer C. E., 2009. IntCal09 and Marine09 radiocarbon age calibration curves, 0-50,000 years cal BP. Radiocarbon, 51: 1111-1150.

Reis D., Vian B., Bajon C., 2006. Le monde des fibres. Paris, Belin. 
Renel F., Mouton M., 2013. The architectural remains and pottery assemblage from the early phases at the Qasr al-Bint. In M. Mouton and S. Schmid (eds.). Men on the Rocks. The Formation of Nabataean Petra, (2-4 December 2011: Berlin). Berlin, Logos Verlag, 57-78.

Russell K. W., 1995. Traditional Bedouin Agriculture at Petra: Ethnoarchaeological Insights into the Evolution of Food Production. Studies in the History and Archaeology of Jordan, 5: 695-696.

Sachet I., Delhopital N., Bouchaud C., Tomé Carpentier C. (in press). The Hellenistic-Nabataean crypt in tower tomb 303 at ath-Thughrah in Petra. Results of the archaeological and multi-disciplinary studies. Annual of the Department of Antiquities of Jordan 58.

Sanlaville P., 2000. Le Moyen-Orient arabe : le milieu et l'homme. Paris, Nathan.

SARTre M., 1982. Inscriptions Grecques et Latines de la Syrie, tome XIII, fascicule 1. Paris, P. Geuthner.

Sartre M., 2007. Période romaine. Le cadre historique. In J. Dentzer-Feydy M. Vallerin T. Fournet R. Mukdad, A. Mukdad (eds.). Bosra Aux Portes de l'Arabie. Beyrouth, IFPO, 25-30.

Simms S. R., Russell K. W., 1997. Bedouin hand harvesting of wheat and barley: Implications for early cultivation in southwestern Asia. Current Anthropology, 38: 696-702.

Studer J., 2007. Animal exploitation in the Nabataean world. In K. D. Politis (ed.). The World of the Nabataeans, Steiner-Verlag, Stuttgart, 251-272.

Tengberg M., 2012a. Beginnings and early history of date palm garden cultivation in the Middle East. Journal of Arid Environments, 86: 139-147.

Tengberg M., 2012b. Fruit growing. In D. T. Potts (ed.). A Companion to the Archaeology of the Ancient Near East. Chichester, Willey-Blackwell, 181-200.

TholbecQ L., 2013. The Hinterland of Petra (Jordan) and the Jabal Shara during the Nabataean, Roman and Byzantine periods. In M. Mouton, S. Schmid (eds.). Men on the Rocks. The Formation of Nabataean Petra, (2-4 December 2011: Berlin). Berlin, Logos Verlag, 295-312.

Tholbecq L., Durand C., Bouchaud C., 2008. A Nabataean rock-cut sanctuary in Petra: second preliminary report on the "Obodas chapel" excavation project, Jabal Numayr (20052007). Annual of the Department of Antiquities of Jordan, 52: 235-254.

VAN der Veen M., 1999. The economic value of chaff and straw in arid and temperate zones. Vegetation History and Archaeobotany, 8: 211-224.
VAN DER VeEN M., 2007. Formation processes of desiccated and carbonized plant remains - the identification of routine practice. Journal of Archaeological Science, 34: 968-990.

VAn der Veen M., 2011. Consumption, Trade and Innovation: Exploring the Botanical remains from the Roman and Islamic Ports at Quseir al-Qadim, Egypt. Africa Magna Verlag, Frankfurt.

Van der Veen M., Fieller N., 1982. Sampling seeds. Journal of Archaeological Science, 9: 287-298.

Villeneuve F., 1985. L'economie rurale et la vie des campagnes dans le Hauran antique. In J. M. Dentzer (ed.). Hauran I: Recherches Archéologiques Sur La Syrie Du Sud À L'époque Hellénistique et Romaine. Paris, P. Geuthner, 63-136.

Villeneuve F., 1990. The Pottery from the Oil-Factory at Khirbet Edh-Dharih (2nd Century AD). A Contribution to the Study of the Material Culture of Nabataeans. Aram, 2: 367-384.

Villeneuve F., 2014. The rampart and the south-eastern gate (Area 35). Survey and excavation seasons 2011 and 2014. In L. Nehmé (ed.). Rapport Sur La Cinquième Campagne (2014) de La Mission Archéologique de Madẩin Sâlih, Paris, 17-73.

Villeneuve F., Al -Muheisen Z., 1994. Découvertes nouvelles à Khirbet edh-Dharih (Jordanie), 1991- 1994 : autour du sanctuaire nabatéen et romain. Comptes-rendus de l'Académie des Inscriptions et Belles-Lettres, 138 (3): 735-757.

Villeneuve F., Al-Muheisen Z., 2008. Le sanctuaire nabatéo-romain de Dharih (Jordanie): nouvelles découvertes, 2001-2008. Comptes-rendus de l'Académie des inscriptions et belles-lettres, 152 (4): 1498-1520.

Wenning R., 2007. The Nabataeans in History. In K. D. Politis (ed.). The world of the Nabataeans. Stuttgart, Steiner-Verlag, 25-44.

Wetterstrom W., 2013. Chapter 12. The plant remains from Khirbet et-Tannur. In J. S. McKenzie, J. A. Greene (eds.). The Nabataean Temple at Khirbet et-Tannur, Jordan, Volume 2. Boston, American Schools of Oriental Research.

Willcox G., 2003. L'économie végétale à Bosra et à Si': résultats d'analyse de restes végétaux carbonisés des périodes romaine, byzantine et islamique. In J. Dentzer-Feydy J. M. Dentzer and P.-M. Blanc (eds.). Hauran II, Beyrouth, Institut français d'archéologie du Proche-Orient, 177-184.

Zohary M., 1973. Geobotanical Foundations of the Middle East. Stuttgart, Fisher.

Zohary D., Hopf M., WeIss E., 2012. Domestication of Plants in the Old World: The origin and spread of domesticated plants in Southwest Asia, Europe, and the Mediterranean Basin. Oxford, OUP Oxford. 